\title{
جريمة استهلاك المخدرات \\ بين العقوبة وتدبير الأمن في التشريع الجزائري
}

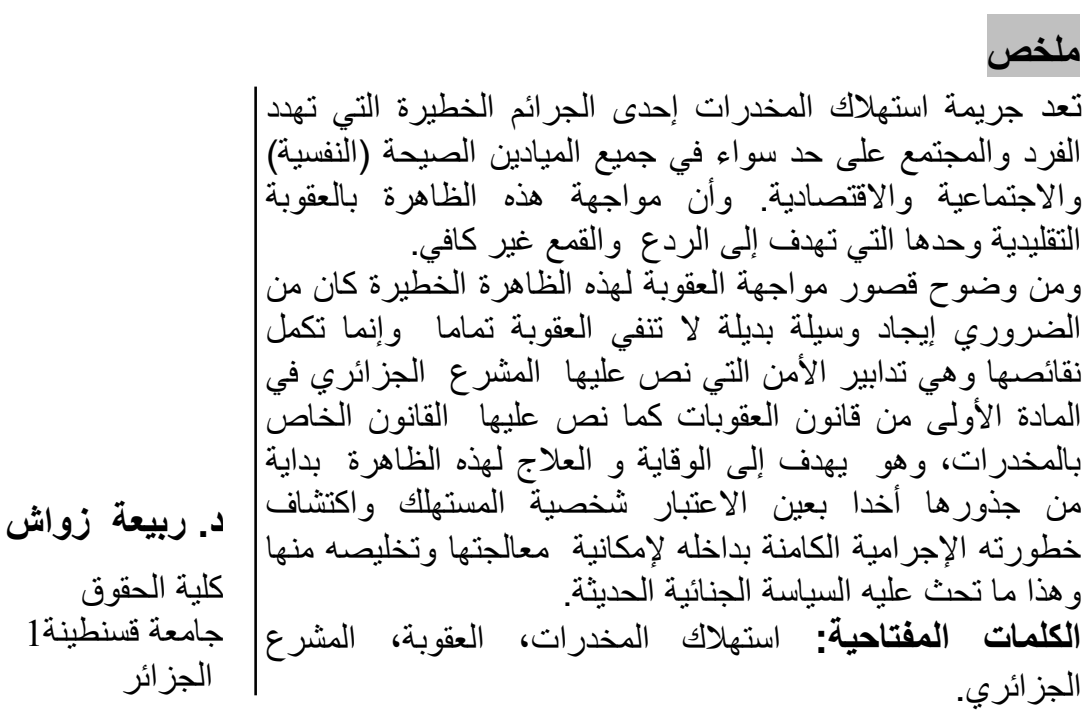

\section{مقدمة Résumé} un grave problème à la fois فإن مظاهر خطرها قد يختلف من دولة إلى إلى sanitaire et économique qui

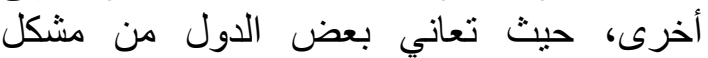
menace l'individu et la société. Le manque d'application des sanctions pour lutter contre ce problème a montré ses limites par satisfaisantes. Donc, il était impératif de trouver un autre moyen qui complète la sanction

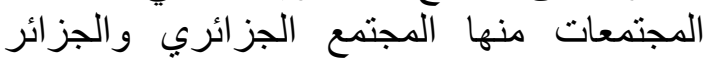

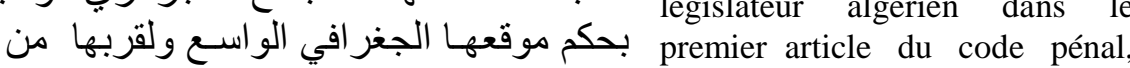
par des mesures prévues par le
législateur algérien dans le 
مواطن الزراعة والتصدير هذه السموم كونها تعد

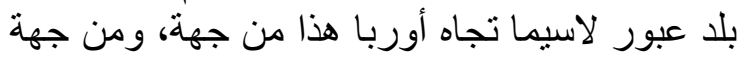

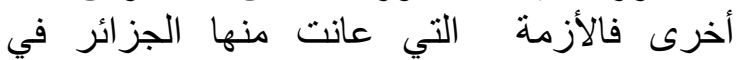
ainsi que le code de drogues, afin de prévenir et traiter ce problème en tenant compte de la personnalité du consommateur et de sa gravité.

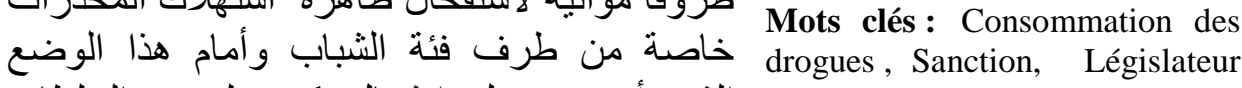
algérien

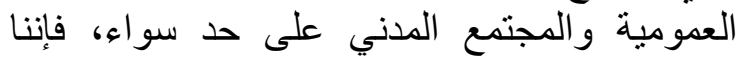

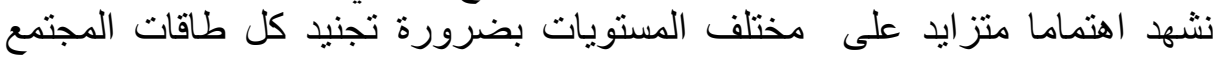

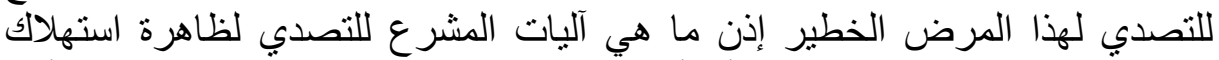

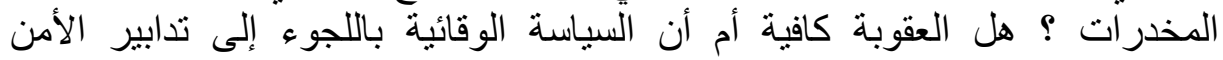
ضرورية في هذا الخصوص؟ هن العوبه هذا ما نريد توضيحه في هذه الدر اسة. الفصل الأول: ماهية جريمة استهلاك المخدرات هذه لورهات

لمعرفة ماهية جريمة استهلاك المخدرات لابد من توضيح المفهوم العام لجريمة

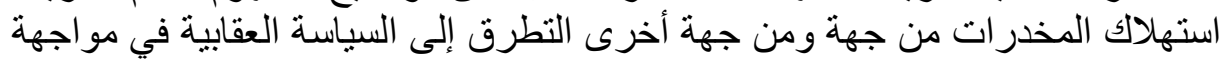
جريمة استهلاك المخدرات.

\section{المبحث الأول:المفهوم العام لجريمة استهلاك المخدرات}

اعتبر المشرع الجزائري استهلاك المخدرات والحيازة من أجل الاستهلاك

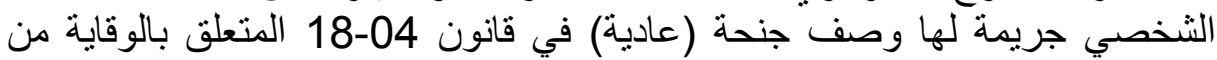

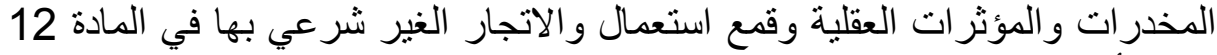

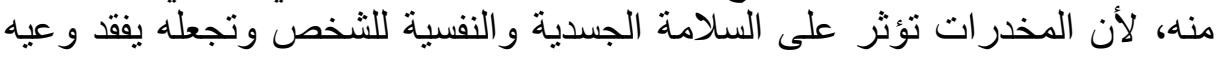

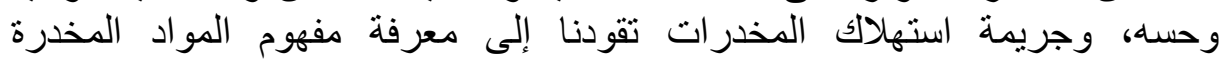

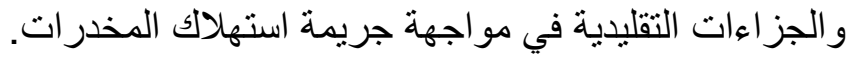

\section{المطلب الأول:مفهوم المواد المخدرة}

نظر الصعوبة إيجاد تعريف جامع للمخدرات على الصعيد الدولي، فقد تم حصر

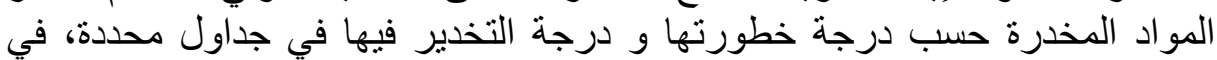

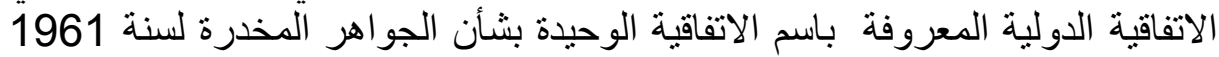
و المعدلة بموجب بروتكول 1972، واتفاقية المواد المؤثرة على الحالة النفسية لسنة التهانة

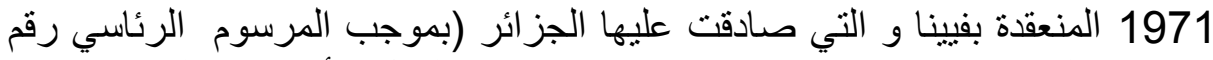
77-77 المؤرخ في 07 ديسمبر 1977) والتزمت الدون الدول الأعضاء الموقعة عليها

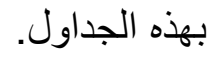

وقد أجتهد الباحثون و العلماء و الققهاء في إيجاد تعاريف عامة للمواد المخدرة. 


\section{الفرع الأول: التعاريف العامة}

يمكن القول أنه لا يوجد تعريف واضح و وامع بين جميع المفاهيم الخاصة بالمخدرات، فيختلف تعريفها اللغوي عن التعريف العلمي لهاو التعريف القانوني.

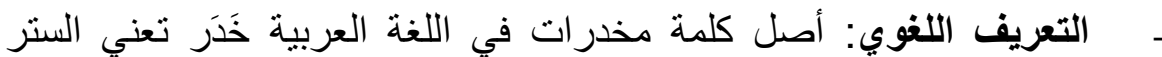
ويقال جارية "مخدرة" إذا التزمت الخدر، أي استترت من هنا استعملت كلمة مخدرات

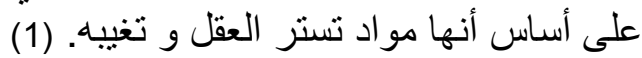

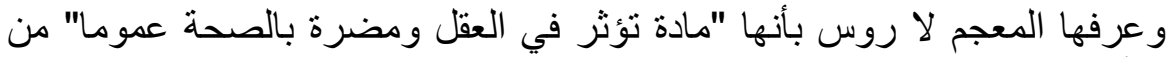

شأنها أن تحدث تسمما، وتستهالك خار ج وصنفة طبية".

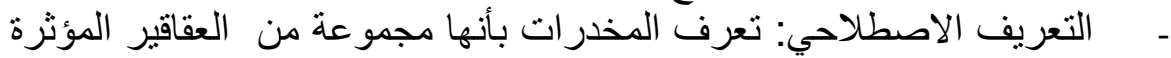

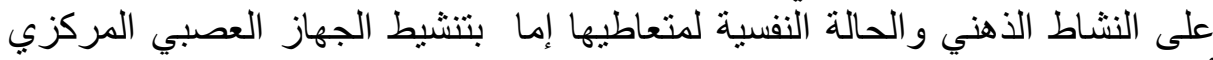
أو بإبطال نشاطه وهي تسبب الهلوسة والتخيلات، وتسبب هذه العقاقير الإدمان وينجم

عن تعاطيها الكثير من المشاكل الصحية واطية والاجنماعية. -

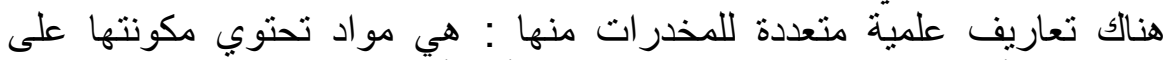

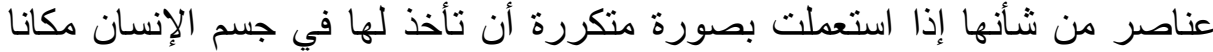
وأن تحدث في نفسه وجسده تغيرات عضوية وفيزيولوجية ونفات ونفية.

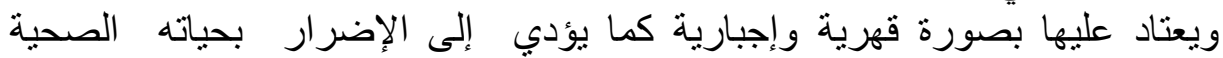
و النفسية والاجتماعية وهذا الضرر يلحق بالفرد نفسه وبأسرته و المجتمع الذي يعيش الإن

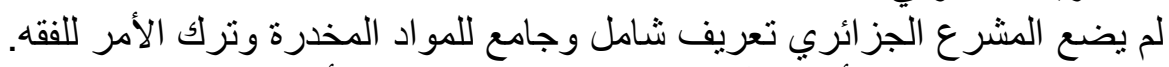

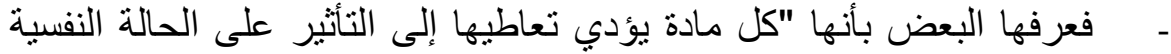

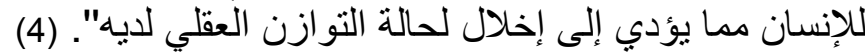

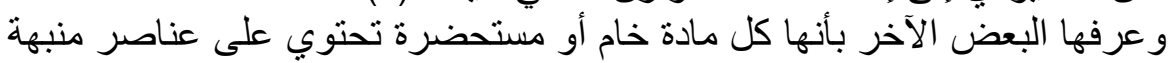

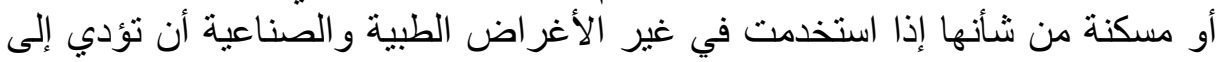
حالة التعود و الإدمان عليها مما يضر بالفرد و المجتمع جسميا ونفسيا و اجتماعيا.

غير أن القانون رقم 18-04توصل إلى تعريف خاص لكل من المخدرات و المؤثرات العقلية في مادته الثانية التي تتص على أنى أنه : "المخدر : هو كل مادة طبيعية

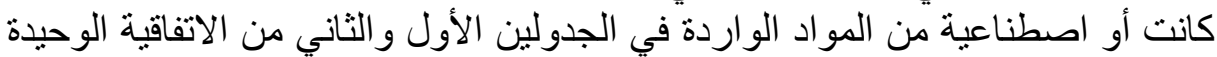

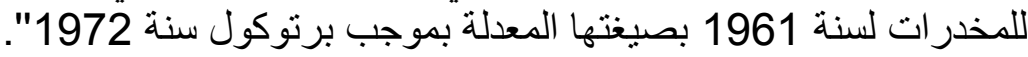

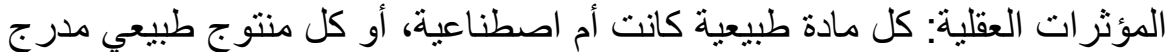
في الجدول الأول أو الثاني أو الثالث أو الثية الرابع من اتفاقية المؤثرات العقلية لسنة (6) . 1971 
و وعليه نكون بصدد مخدر غير مشروع إذا كان القانون يحظر إنتاجه أو حيازته إنها

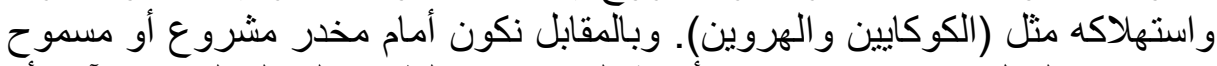

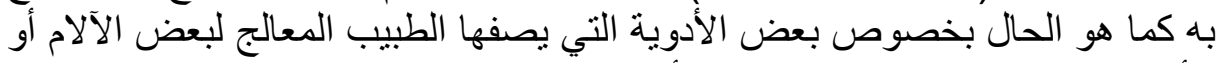

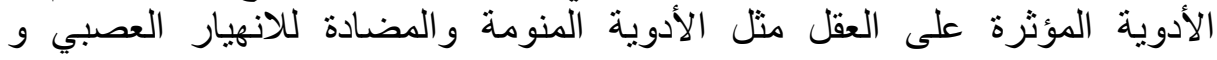

\section{الفرع الثاني: تصنيف المواد المخدرة}

تتعدد المعايير المتخذة أساسا لتصنيف المواد المخدرة تبعا لمصدر ها أو طبقا لأصل إلى المبل المادة التي حضرث المعاير منها وتنقسم طبقا لهذا المعيار إلى:

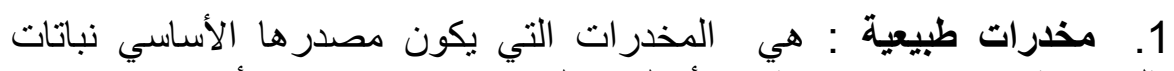

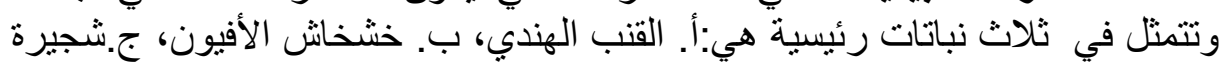

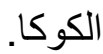

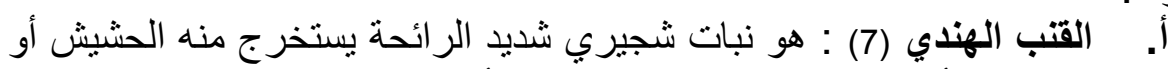

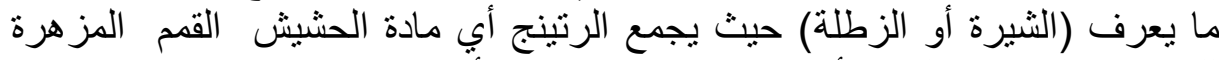

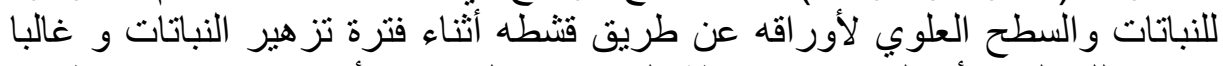

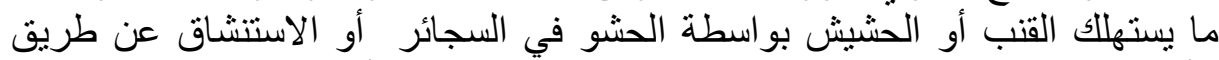

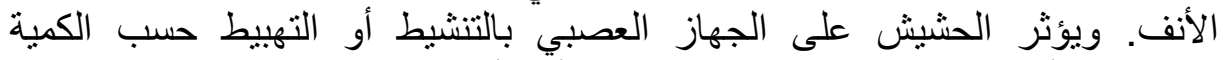

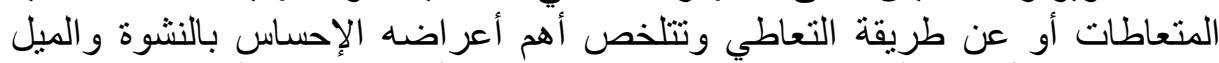

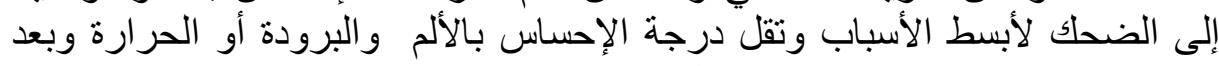
انتهاء مفعوله يشعر المتعاطي بالخمول والابن والاكتئناب.

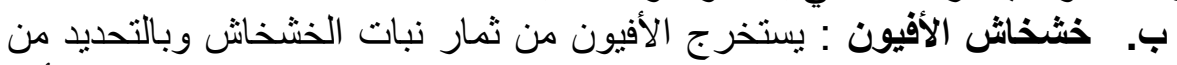

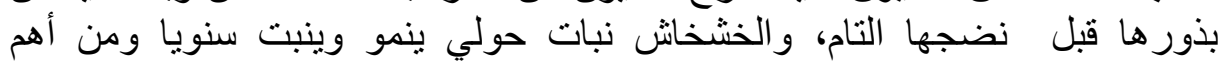
مشتقاته مخدر ات المورفين.

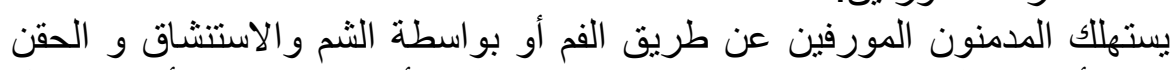

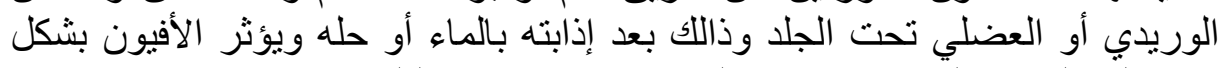

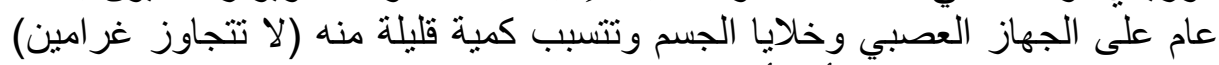

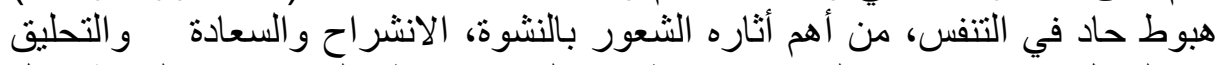

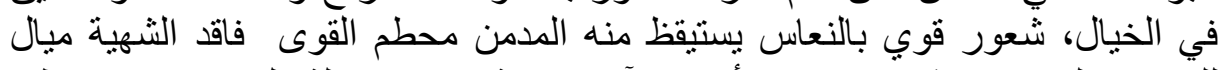

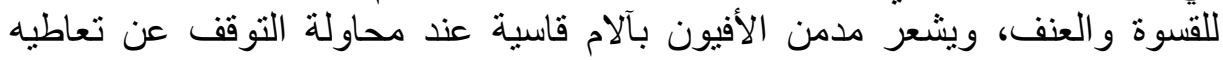

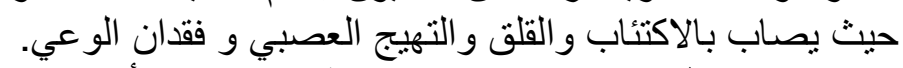

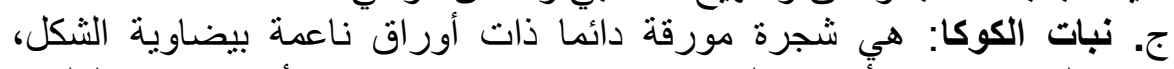

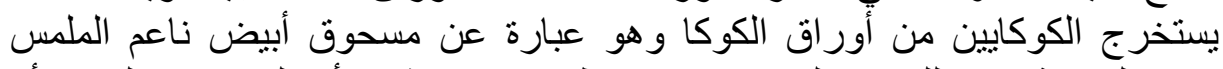

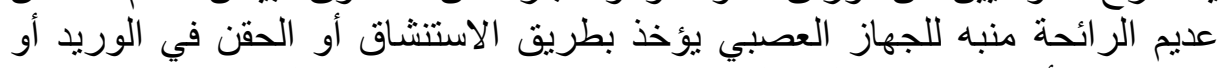

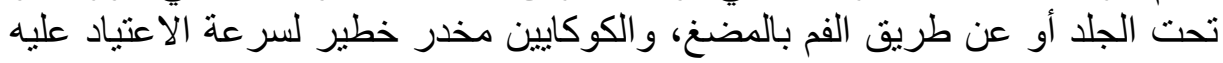

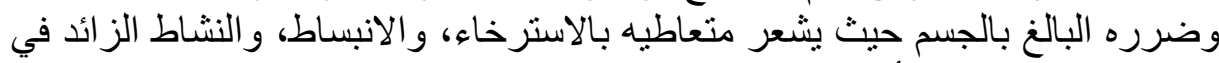

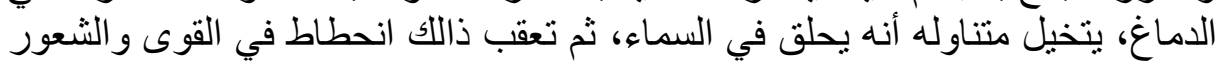


بالحزن واليأس والكسل وسر عان ما بسلب الكوكايين إرادة مدمنه و بيتعبده

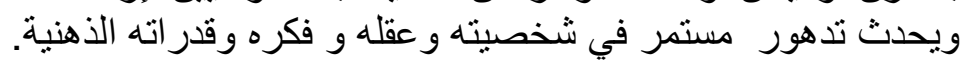

2.

مستخلصة من النباتات المخدرة والتي تكون المادة الناتجة من هذا التفاعل ذات اتفاعن تأثنير

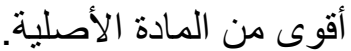

أ. ألمورفين : أصبح في بداية القرن 19 من الممكن تحليل مادة الأفيون

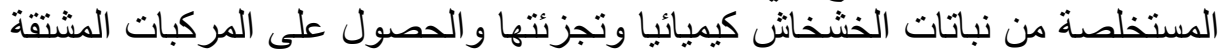

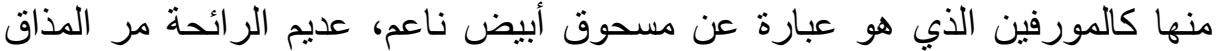

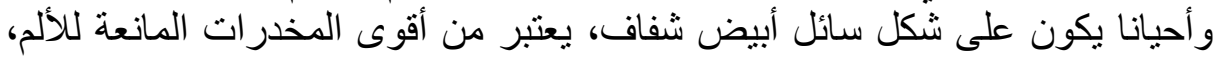

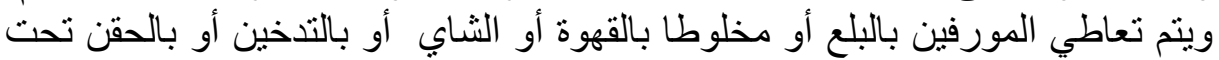

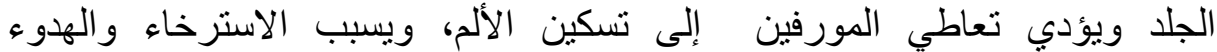

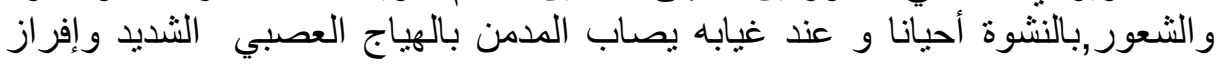

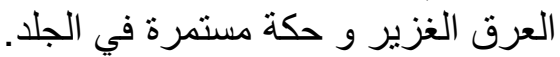

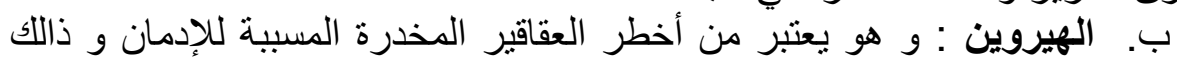

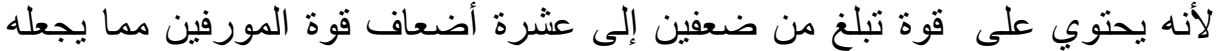

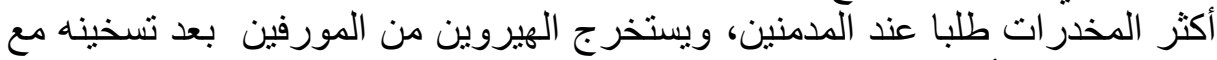
كمية كبيرة من أستيل كلوريد.

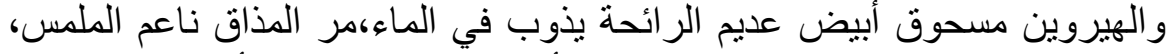

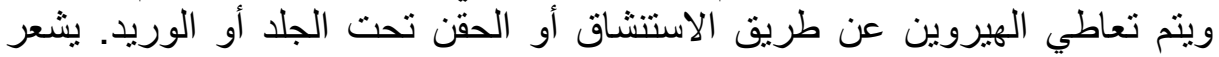

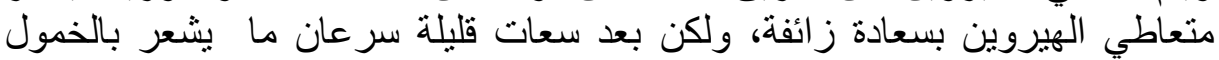

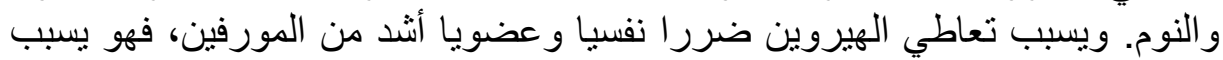
الإدمان أكثر من أي مخدر آخر.

3. المخدرات التخليقية : وهي عبارة عن مستخلصات ناتجة عن التفاعلات

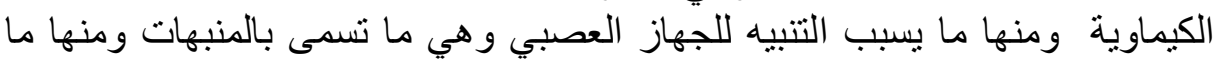

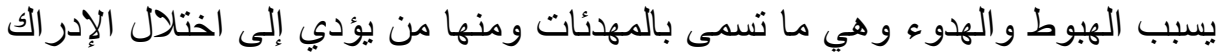

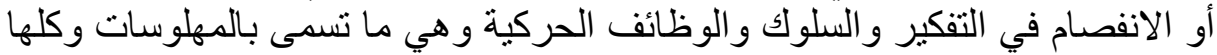
تسبب أضرارا بالمجتمع بصفة الفير عامة وبالفرد بصفة خاصنة.

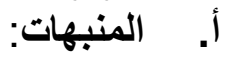

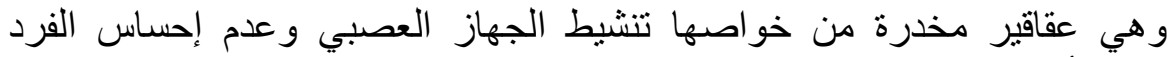

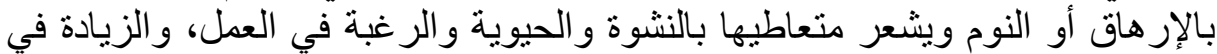
التركيز (8) مثل الأميفيتامينات.

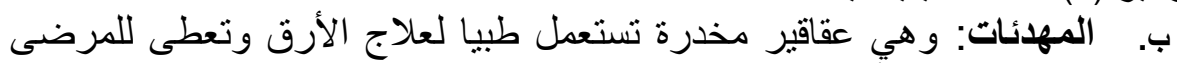

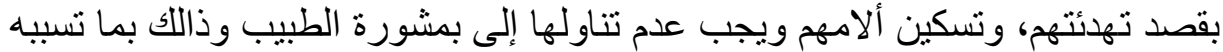

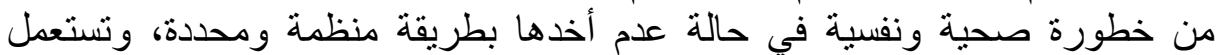

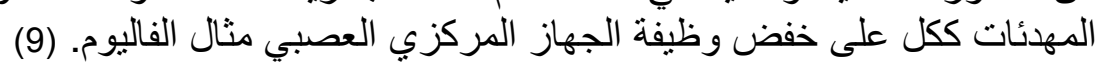


ج. المهلوسات : هي مجموعة من المواد الكيماوية التي تسبب لمستهلكها

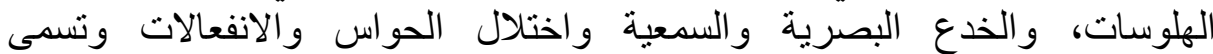

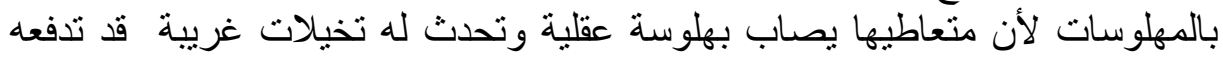

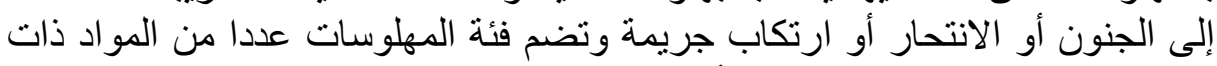

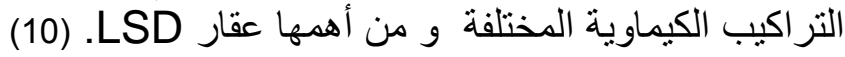

\section{الفرع الثالث: الحكمة من تجريم المخدرات:}

تعتبر المخدرات من المواد السامة. وإن كان قليلا منها قد يكون فيه علاج إلا أن

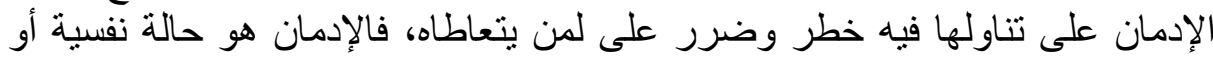

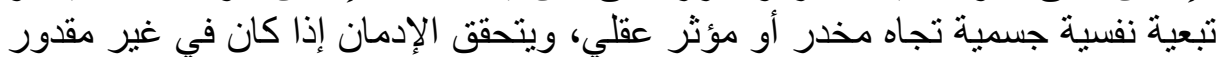

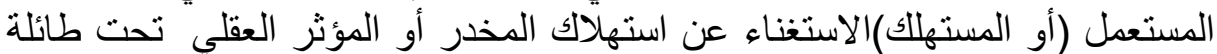

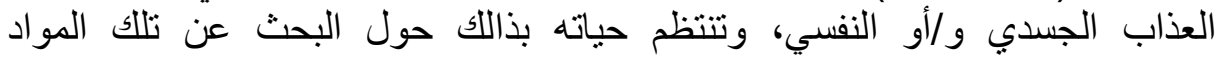
واستهلاكها.

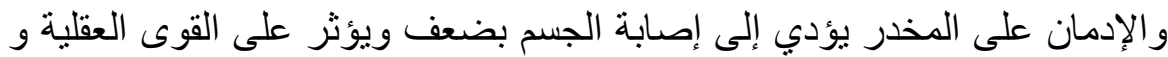

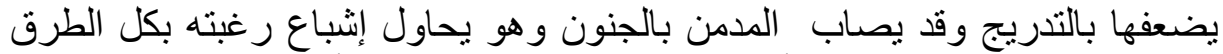

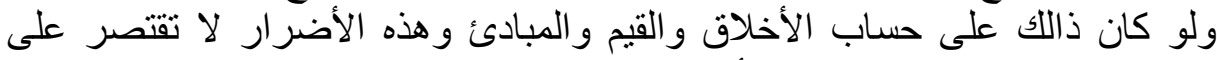

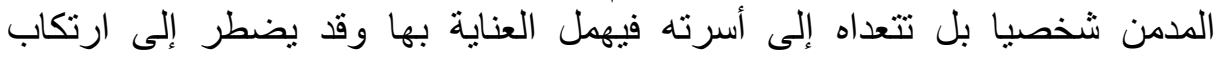

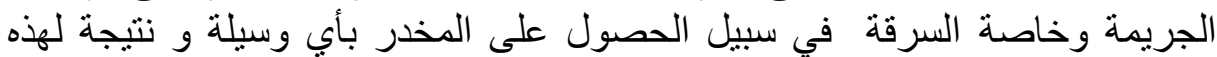
الأضر ار فقد أجمعت غالبية التشريعات ومنها التشريع الجزائري على التى مكافحة الإدمان

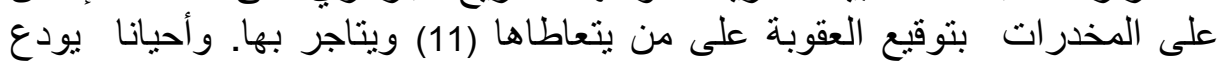
المدمن في مصحات ليعالج من عادة الإدمان. المطلب الثاني : أركان جريمة استهلاك المخدرات جريمة استهلاك المخدرات ككل الجرائم تقوم على أركان ثلاثة هي: الركن الركن الثرعي و الركن المادي و الركن المعنوي.

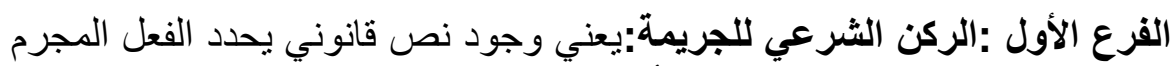

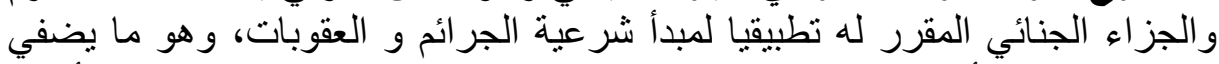

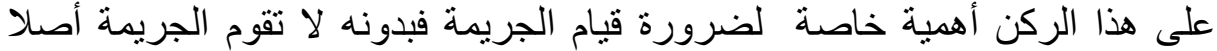

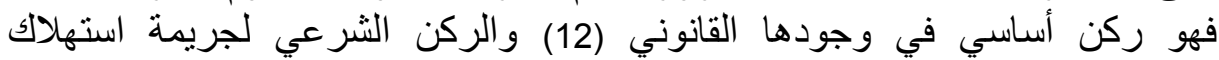

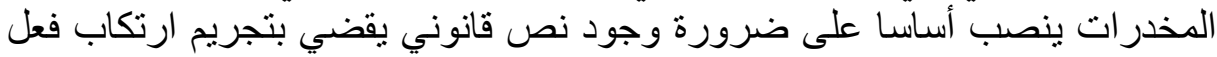

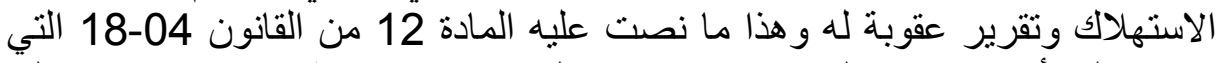
تنص على أنه "يعاقب بالحبس من شهرين إلى سنتينو بغرامة من من

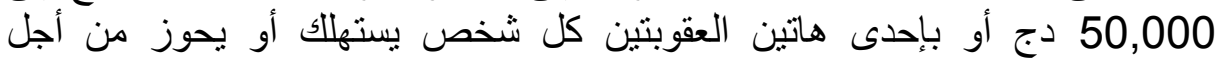

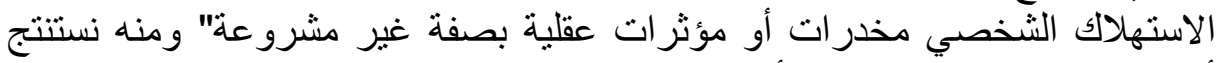
أن جريمة استهلاك المخدرات أو المؤثرات العقلية جريمة لها وصف جنحة. 
الفرع الثاني :الركن المادي للجريمة:

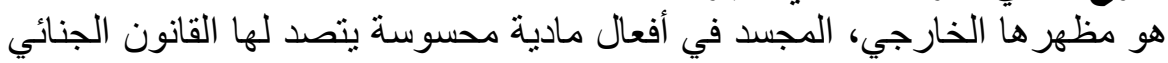
ويعاقب عليها، ويتكون الركن المادي لجريمة الاستهلاك من الفعل المادي المتمثل في

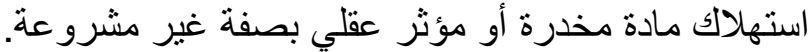

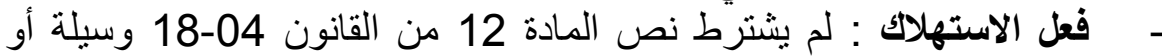

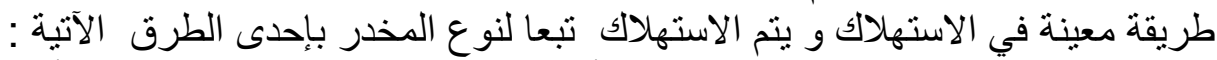

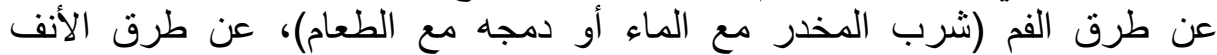
(استتشاق المسحوق أو أبخرة) بواسطة التدخين (بحشوه في سيجارة كما هو الحون الحال بالنسبة لمخدر الحشيش أو الكوكاين)، بواسطة العشة الحقن.

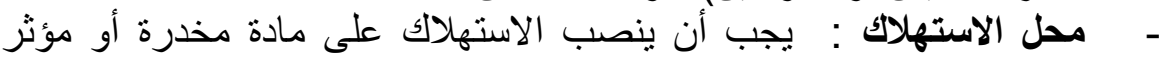
عقلي، وقد يكون مصدره نباتي مثل القنب أو (الكيف) أو الأفيون أو أحد مشتقاته أو أو أو أو كيمائي كما هو الحال بالنسبة لمعظم المؤثرات العقلية مثل الفاليوم...... .

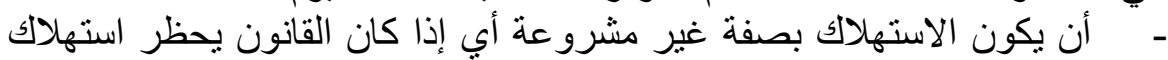

\section{الفرع الثالث:الركن المعنوي للجريمة:}

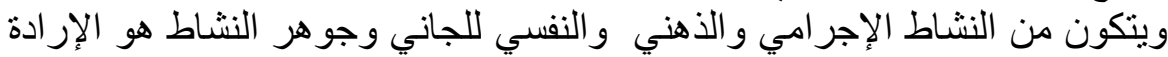

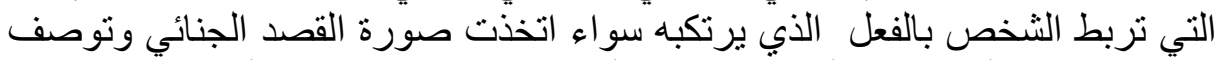

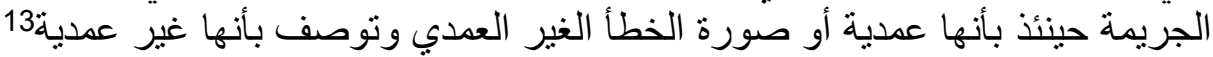
ولا بتحقق الر كن المعنوي في الجرائم العمدية إلا إذا توافير العر القصد الجنائي عند

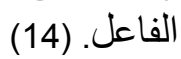
و القصد الجنائي يقوم على عنصر ين هما العلم و الإر ادة.

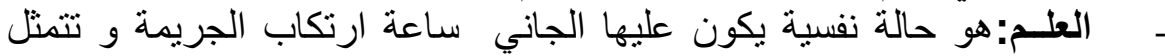

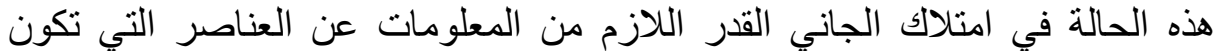

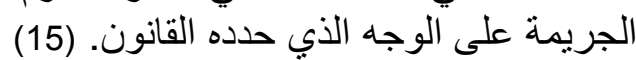

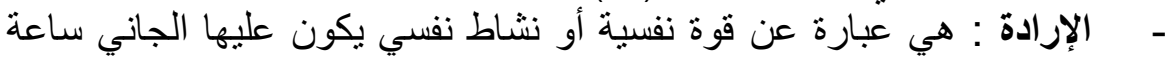

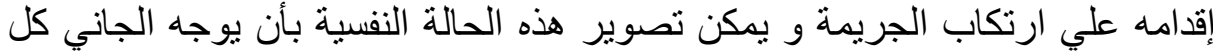

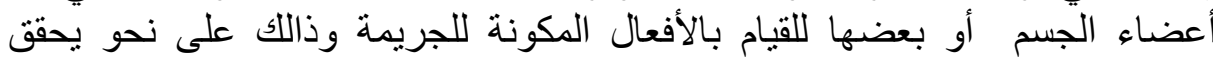
غرض غير مشروع أي نحو المساس بحق أو مصلحة يحميها القانون الجنائي (الخطأ الجنائي). بالنسبة لجريمة استهلاك المخدرات نحن بصدد جريمة عمدية يتمثل الركن

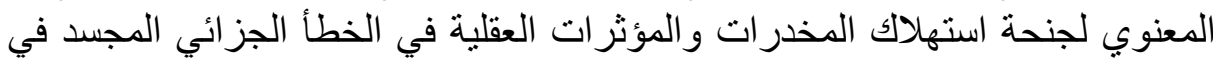

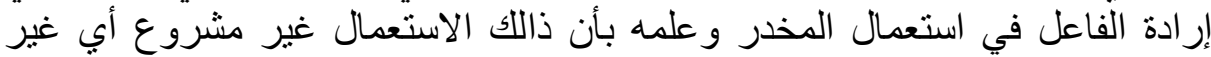

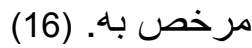
المبحث الثاني: السياسة العقابية التقليدية في مواجهة جريمة استهلاك المخدرات يعتبر الجزء الجنائي بمثابة رد فعل اجتماعي إزاء الجريمة ومرتكبها، وقد كانت 


$$
\text { العقوبة قديما هي الصورة الوحيدة للجز اء الجنائي. }
$$

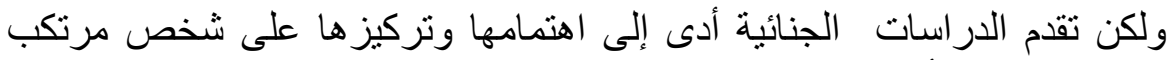

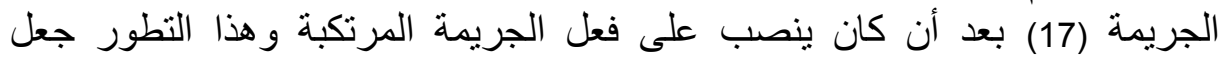

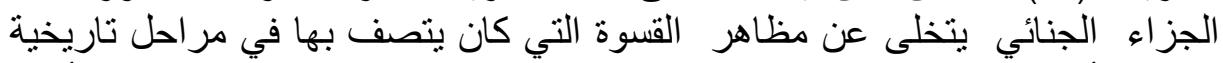
سابقة، فأصبح يتسم بمظاهر إنسانية، التي تهدف إلى إلى إعادة إصلى إنلاح الجاني وتأهيله

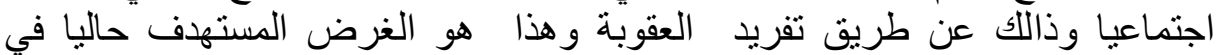

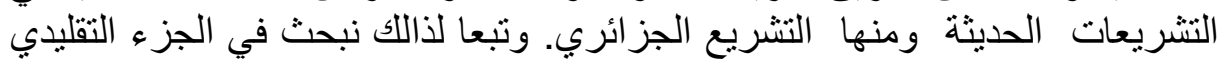

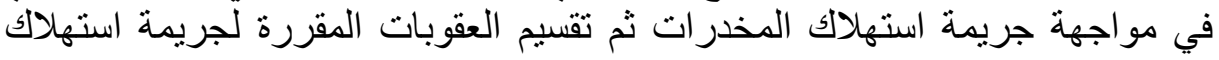

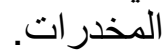

\section{المطلب الأول : الجزاء التقليدي في مواجهة جريمة استهلاك المخدرات :}

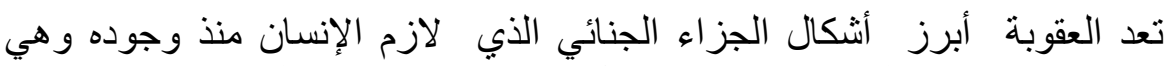

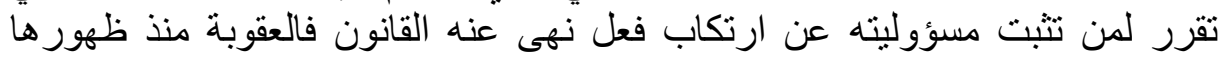

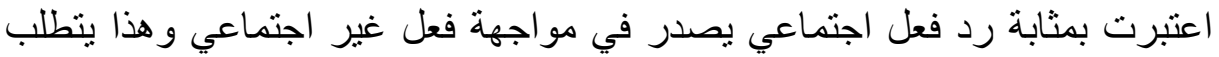

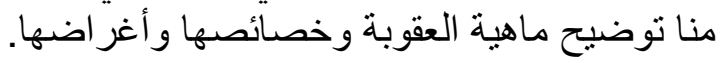

الفرع الأول : ماهية العقوبة: هناللك تعريفات عديدة للعقوبة من طرف وفئه الفقهاء

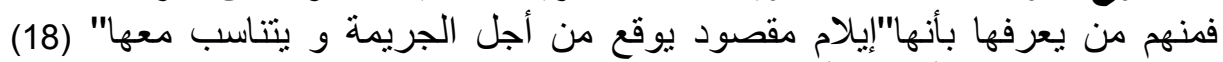

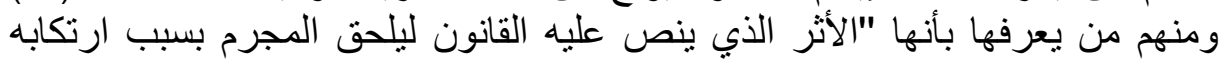

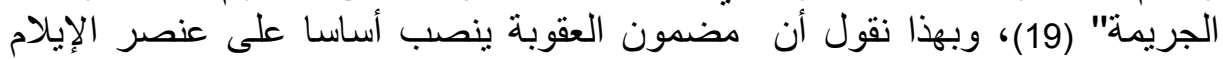

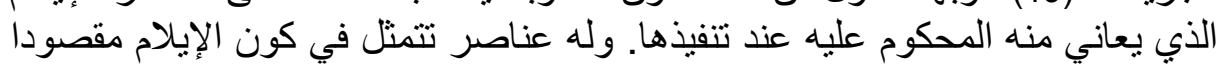
ويرتبط بصلة مع الجريمة.

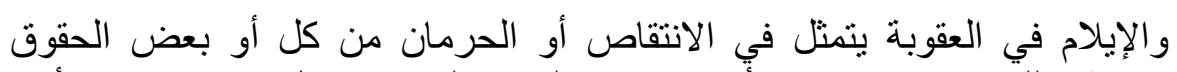

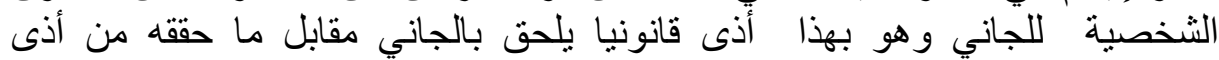

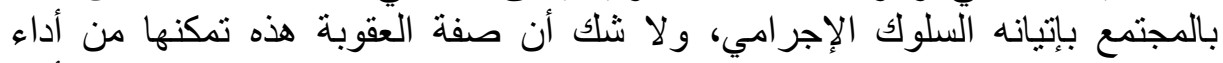

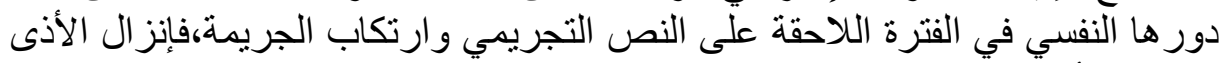

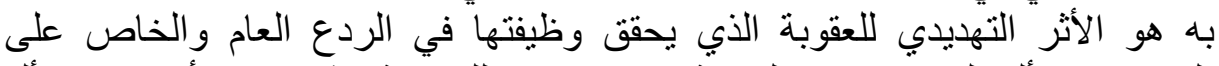

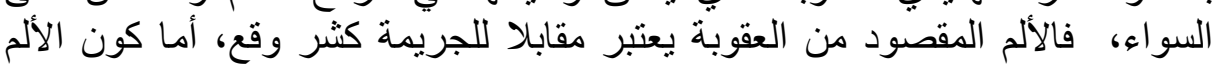

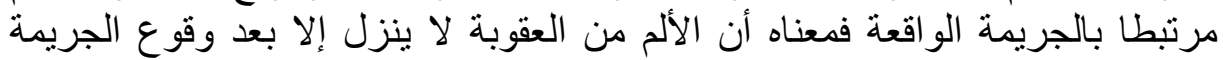

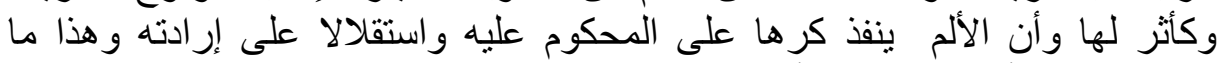
يعطي للعقوبة أكثر دراجات المهات ألمها. (20)

وعقوبة جنحة استهلاك المخدرات في التشريع الجزائري تحددها المادة 12 من

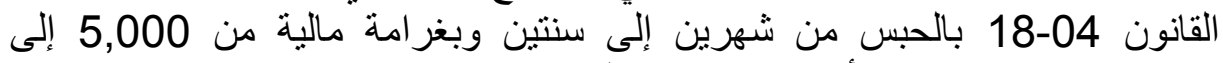
50,000 دينار جزائري أو بإحدى هاتين العقوبتين.

الفرع الثاني خصائص العقوبة: 
للعقوبة خصائص مشتركة لا تشاركها فيها الجزاءات الأخرى وهذه الخصائص

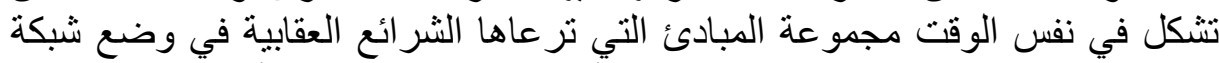

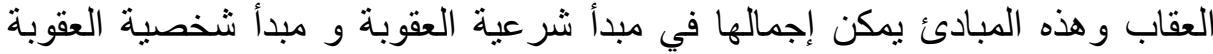
ومبدأ المساو اة في العقوبة ومبدأ قضائية العقوبة.

- مبلأ شرعية العقوبة : ومعناه لا يجوز توقيع عقوبة لم ترد بالنص الجنائي

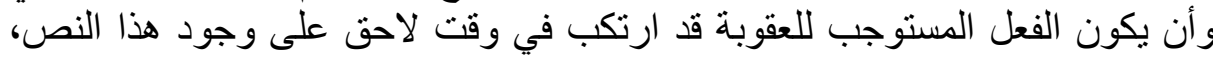

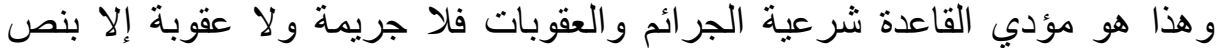

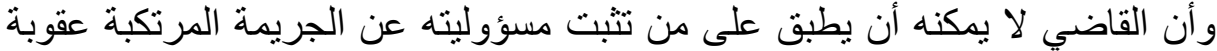

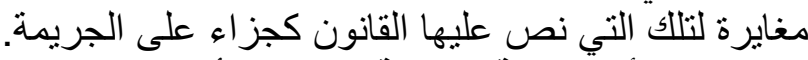

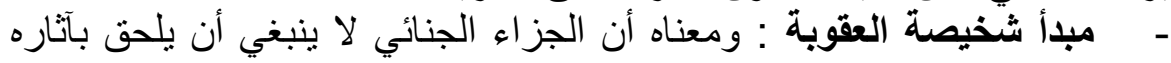

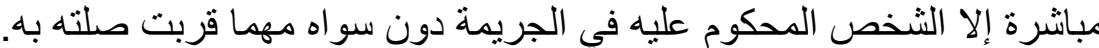

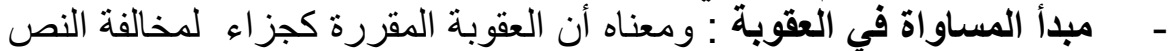

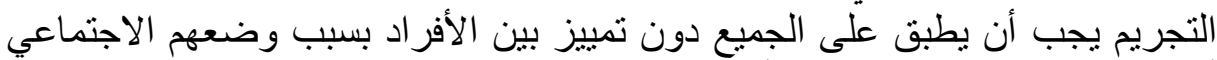

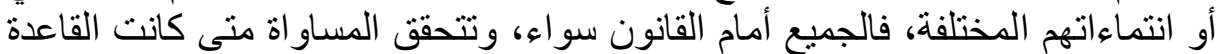
الجنائية المتضمنة للجريمة والعقوبة لهابة لها صفة العمومية وصفة التهانة التجريد.

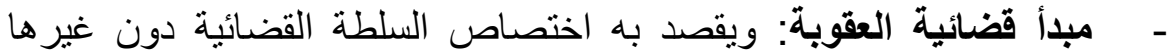

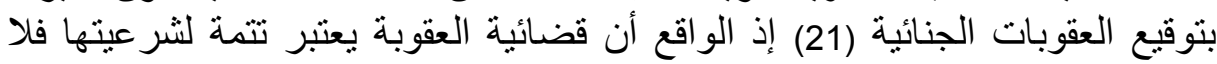
عقوبة إلا بنص ولا عقوبة إلا بحكم قضائي

\section{الفرع الثالث أغراض العقوبة:}

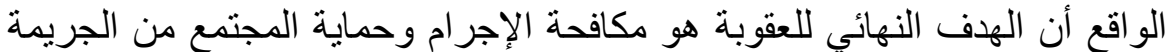

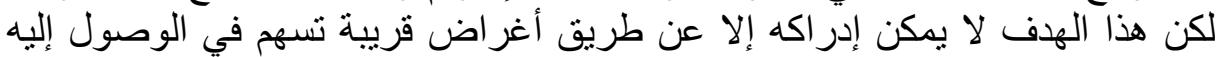
وأغراض العقوبة في العصر الحديث تتحصر في نوعين أحدهما معنوي يتمثل في في تحقيق العدالة والثاني نفعي يتمثل في الردع الذي الذي يقي المجنمع من تكرار الجريمة في في إني المستقبل سو اء من مرتكبها (الردع الخاص) أو أو غيره الأي (الردع العام).

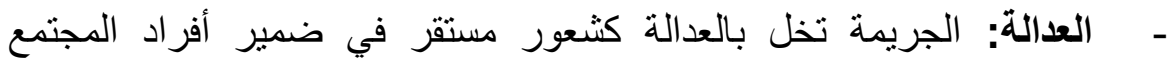
والعقوبة هي رد الفعل الاجتماعي الذي يهدف إلى إعادة الشّعور بالعدالة كما كانت عليه قبل ارتكاب الجريمة. - الردع الخاص : ويتو افر بما تؤثر به العقوبة على نفسية الجاني ذاته لمنعه من

ارتكابه جر ائم مستقبلية. (22)

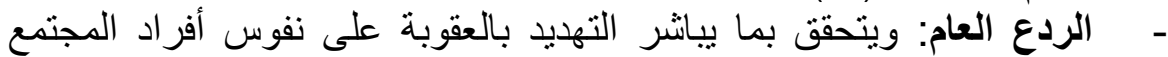
الآخرين (خلافا للجاني) من أثر، بحيث ينفر هم من الجريمة و يصرفهر عن التفكير في في لفي

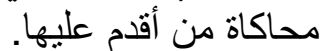

وخلاصة القول أن أفضل نظام عقابي هو الذي يجمع بين هذه الأغر اض و و ينسق بينها حتى يتحقق الهذف من العقاب وهو حماية المجتمع من الجريمة وهذا هذا ما يهذف 
إليه المشرع الجزائري من خلال عقوبة جريمة استهلاك المخدرات.

\section{المطلب الثاني:تقسيم العقوبات المقررة لجريمة استهلاك المخدرات:}

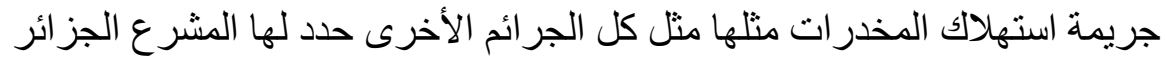

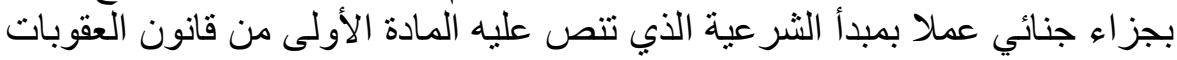

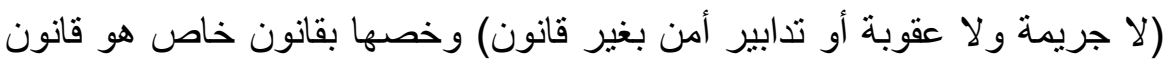

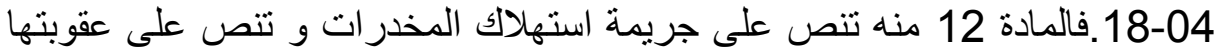

التي تتراوح من (شهرين إلى سنتين) وغر امة (18) (5,000 دج إلى إنى

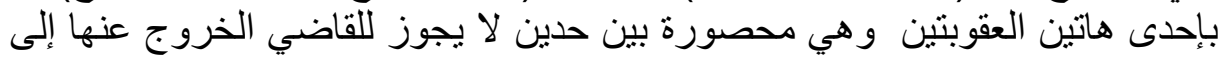

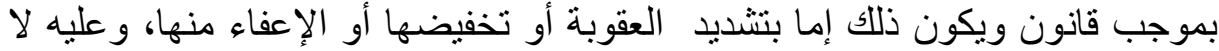

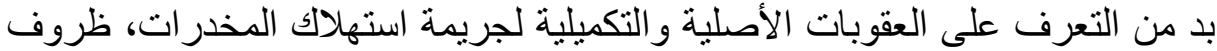
التشديد والتخفيف ثم الأعذار القانونية المقررة لهاتية

الفرع الأول العقوبات الأصلية والتبعية لجريمة استهلاك المخدرات:

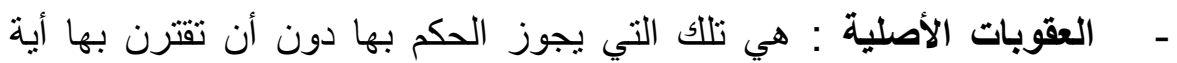
عقوبة، والعقوبات الأصلية المقررة في لجريمة استهلاك المخدرات حسب القات القانون

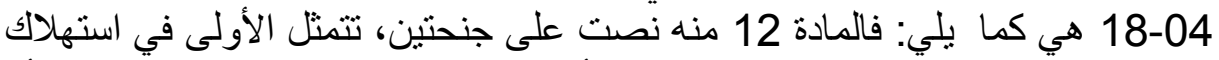

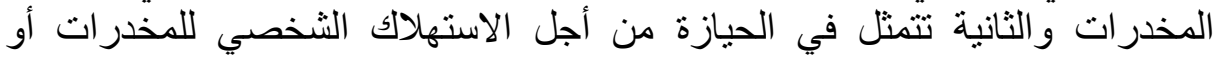
المؤثرات العقلية والتي قرر لها المشرع عقوبة الحبس من (شهرين إلى سنتين)

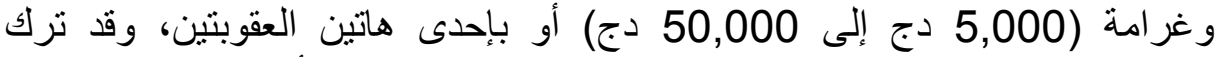

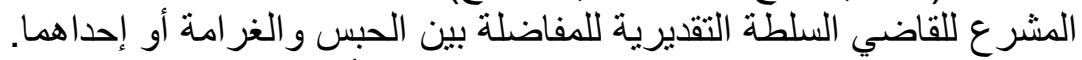

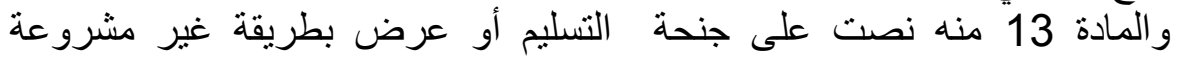

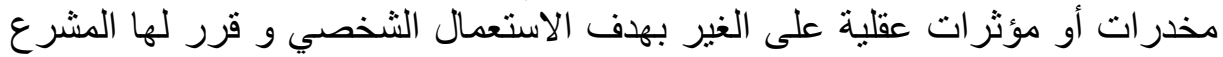

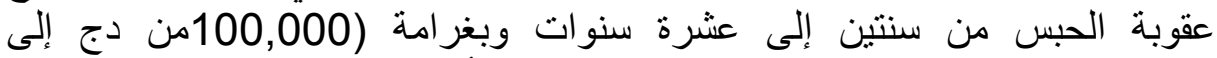

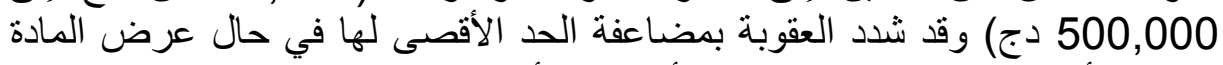

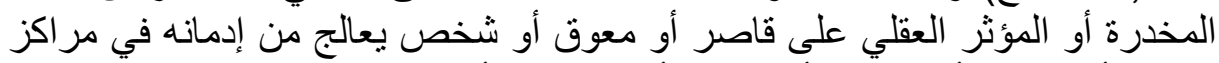
تعليمية أو تربوية أو تكوينية أو صحية أو اجتماعية أو داخل هيئات الو عمومية الونية

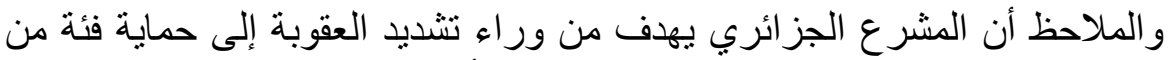

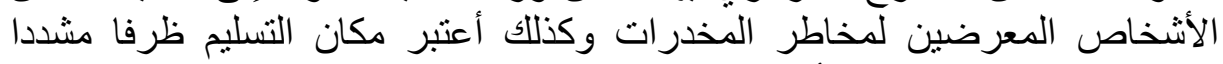
و عاقب عليه بضعف الحد الأقصى للعقوبة المقررة.

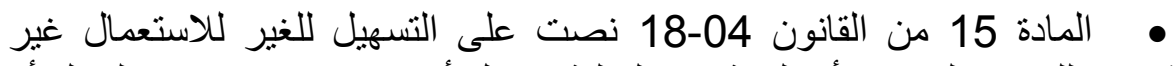

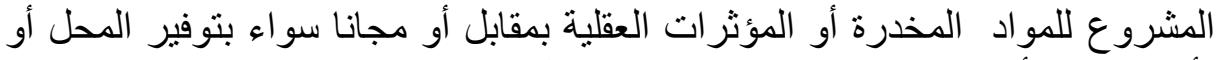

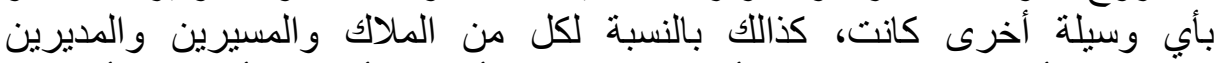

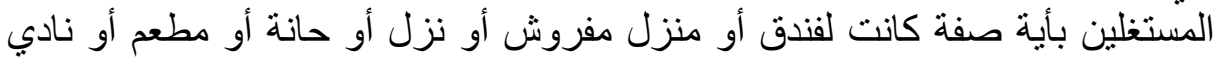

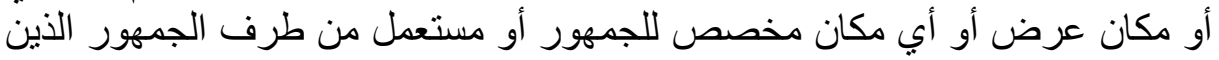




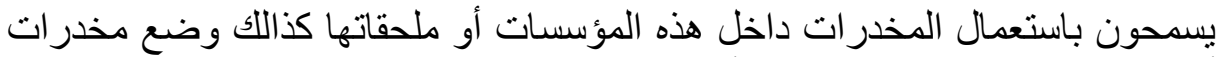

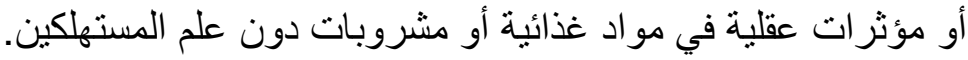

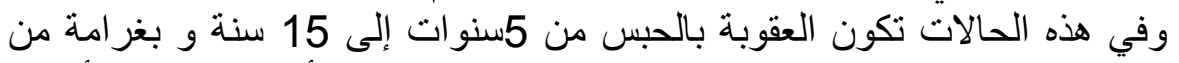

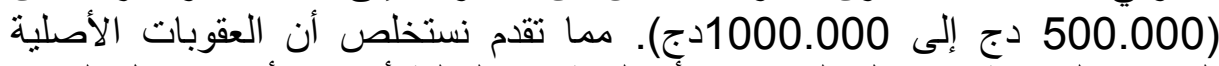

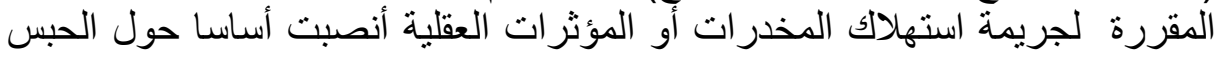

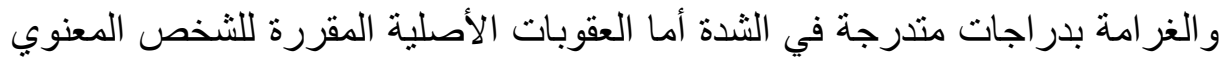

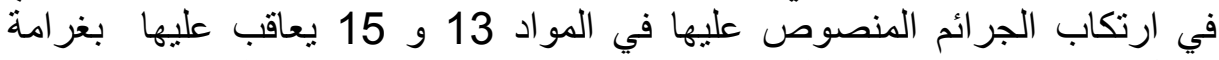
تعادل خمس مرات الغر امة المقررة لشخص طبيعي و هذا ما تتص عليه المادة 25 من

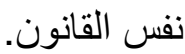

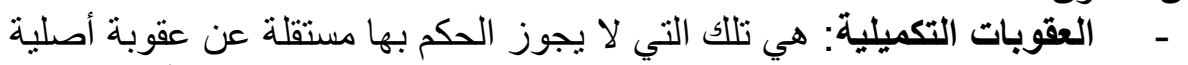

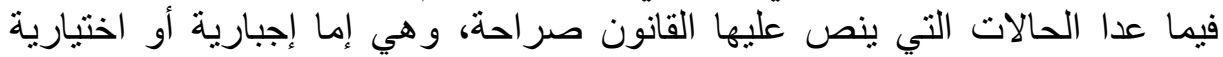

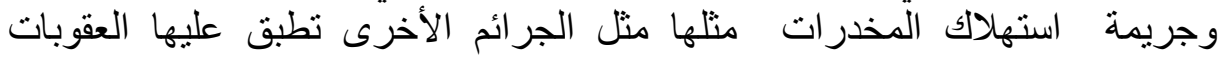

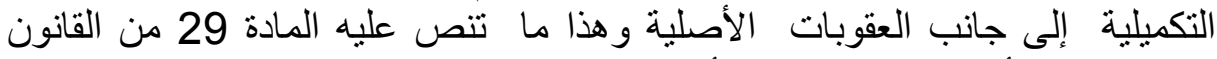

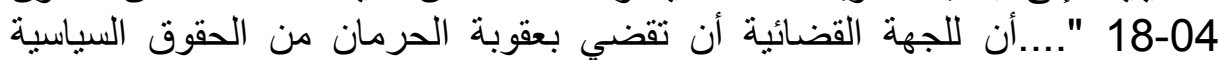
و المدنية والعائلية من خمس سنوات إلى عشر سنوات ويجوز لهازية زيادة على ذللك الحكم

- - - المنع من الإقامة وفقا للأحكام المنصوص عليها في قانون العقوبات.

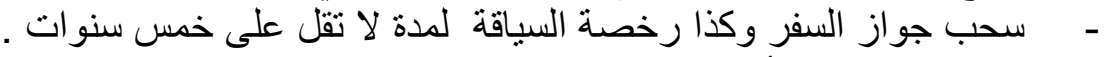

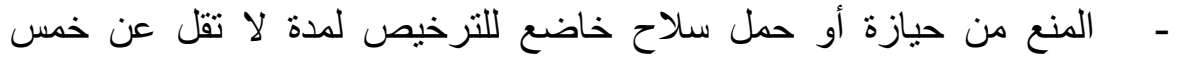

سنوات. مصادرة الأشياء التي استعملت أو كانت موجهة لارتكاب الجريمة أو الأشياء

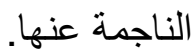

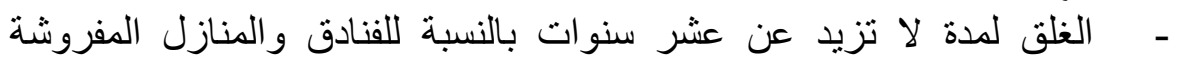

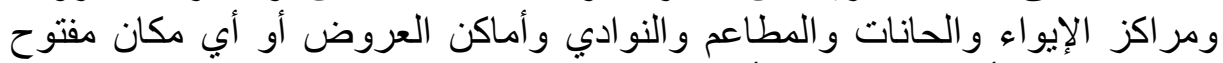

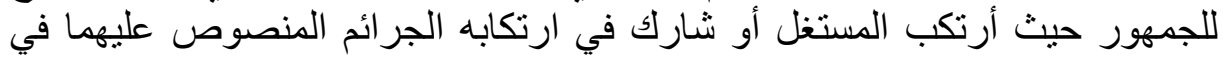
المادتين 15و 16 من هذا القانون.

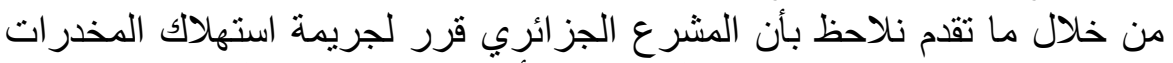

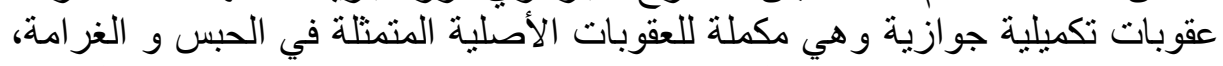

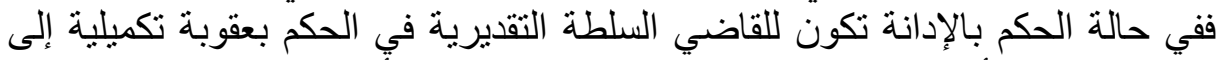

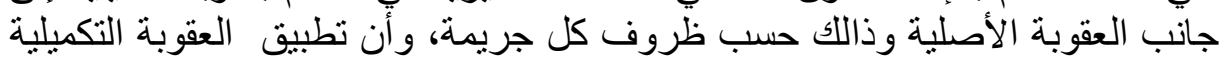

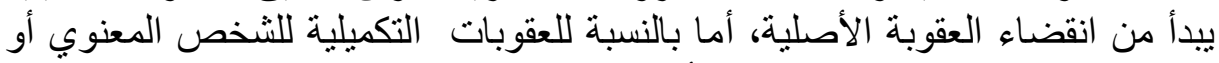

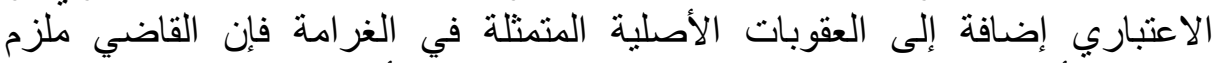

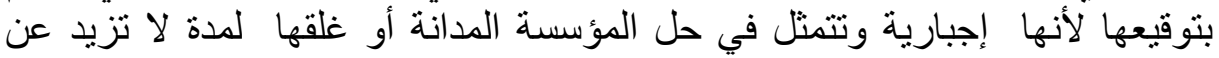

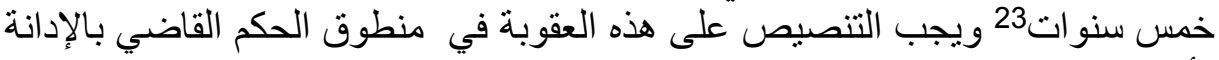

لأنها لا تقع بقوة القانون. (24) 
الفرع الثاني : الظروف المشددة والمخفقة المقررة لجريمة استهلاك المخدرات: •

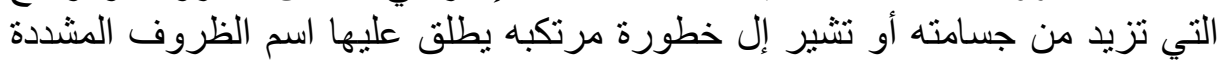

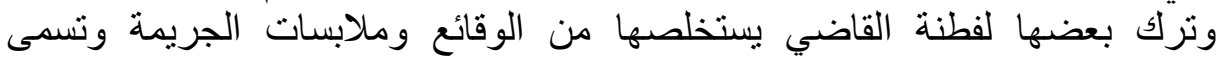

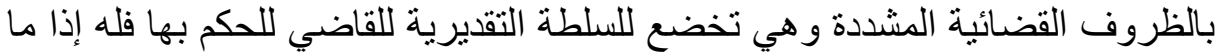

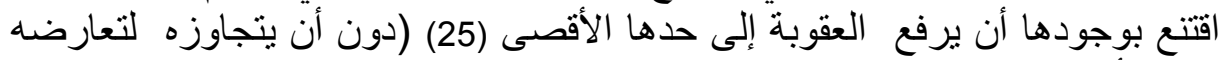

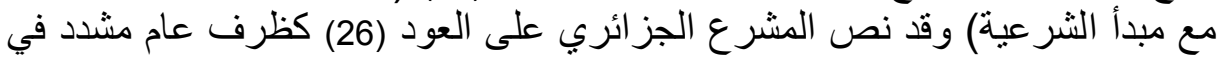

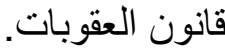

ويقصد بالعود: الوصف القانوني الذي يلحت بشخص عاد باد إلى الإجرام بعد الحكم

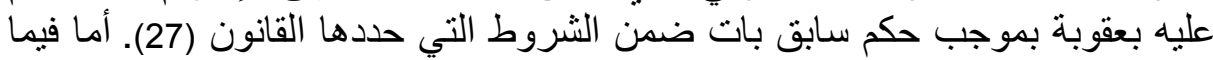

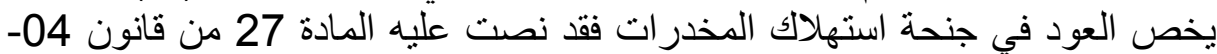
18 "في حالة العود تكون العقوبة التي يتعرض لها مرتكب الأفعال المنصوص علئ عليها في هذا القانون كما يأتي:

ـالسجن المؤبد: عندما تكون الجريمة معاقب عليها بالحبس من 10 سنوات إلى 20

- السجن المؤقت: من عنر سنوات إلى عشرين سنة عندما تكون الجريمة

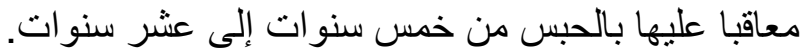
- الععف العقوبة المقررة لكل الجر ائم الأخرى".

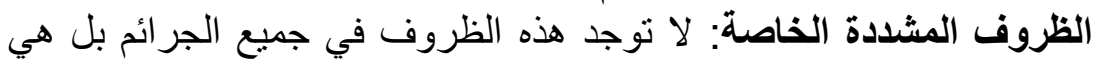

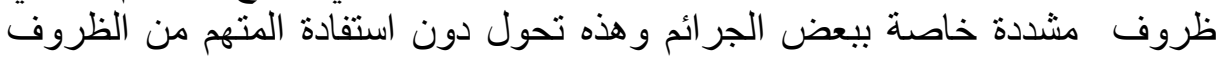

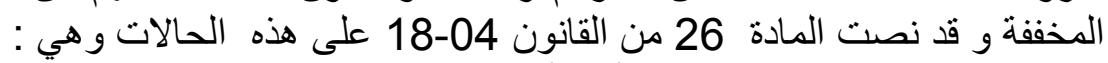
1.

2. إذا كان الجاني يمارس وظيفة عمومية وارتكبت الجريت الجريمة أثناء تأدية وظيفته. 3. إذا ارتكب الجريمة ممتهن في الصحة أو شخص مكلف بمكافحة المخدرات

4. إذا تسبيت المخدرات أو المؤثرات العقلية المسلمة في وفاة شخص أو عدة أشخاص أو إحداث عاهة مستديمة.

5. إذا أضاف مرتكب الجريمة للمخدر ات مواد من شأنها أن تزيد من خطورتها.

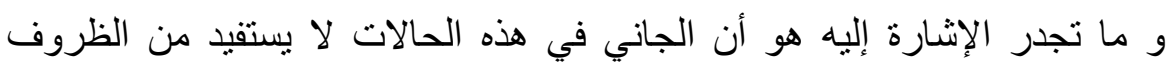

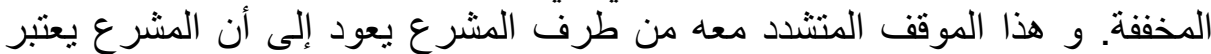
الجاني ذو شخصية خطيرة و لا فائدة من منحه ظروف طرف مخففة.

الظروف المخففة: تتص القوانين عادة على حدين للعقوبة (في مواجهة

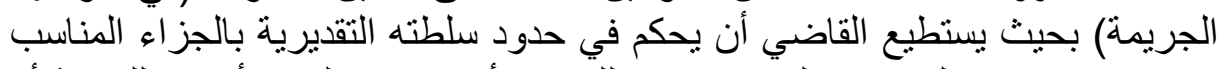
ضمن حدود هذين الحدين و عليه فلا يجوز للقاضي أن يتجاوز الحد الأقصى للعقوبة أو الحد الأدنى المقرد لهاين عملا بمبدأ الثرعية. 
غير أن هذا الأمر يبدو قاسيا في بعض الحالات وذالك عندما يقترن وقوع الجريمة

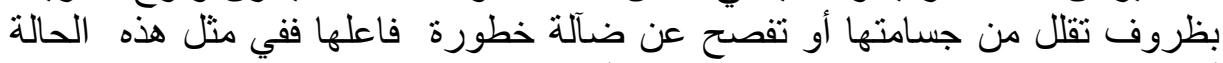

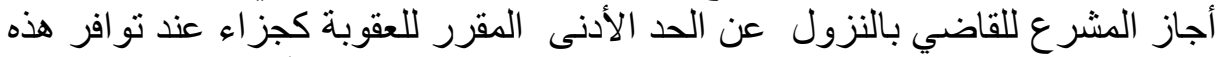
الظروف المخففة (28). و لكنه رسم للقاضي الحدود التراني التي يمكن لله أن ينزل إليها.

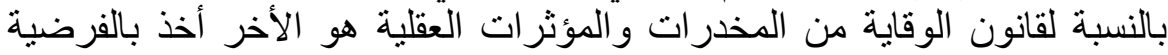

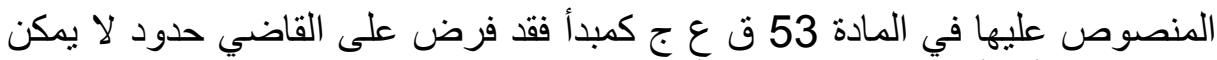

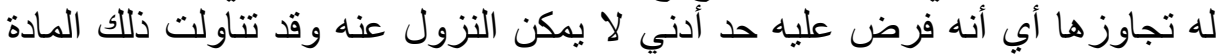
28 بحيث نصت على أنه "العقوبات المقررة في هذا القانون غير قابلة للتخفيض

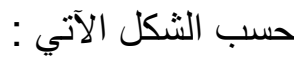
- - عشرون سنة سجنا عندما تكون العقوبة المقررة هي السجن المؤبد. - لثنا(2/3) العقوبة المقررة في كل الحالات".

و عليه يمكننا أن نقول أن جريمة استهلاك المخدرات و الجر ائم المرتبطة بها تطبق عليها الفقرة الثانية من المادة 28 كما يليه :

-

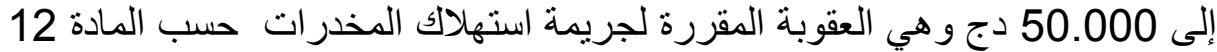

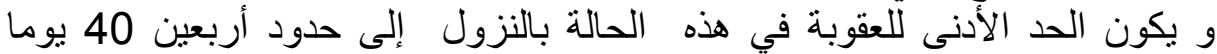

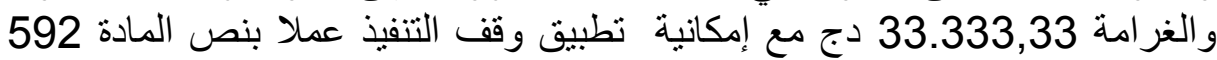

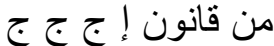
- من إذا كانت العقوبة المقررة هي الحبس من سنتين إلى خمس سنوات

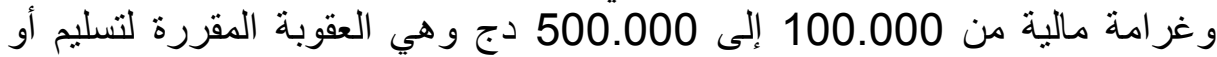

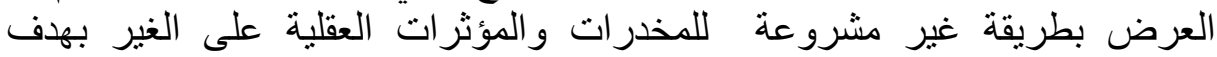

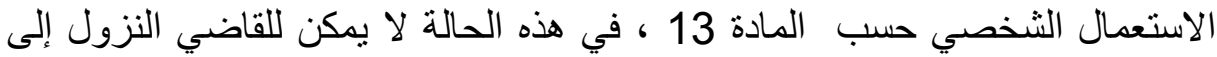

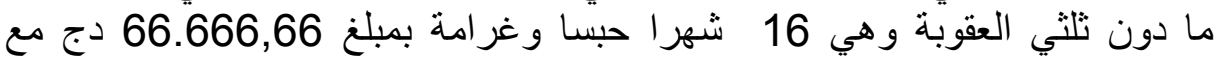

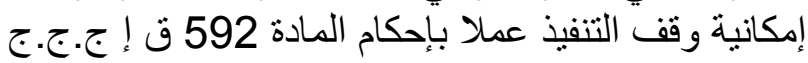

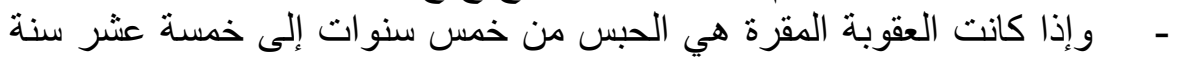

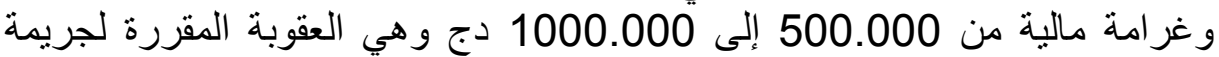

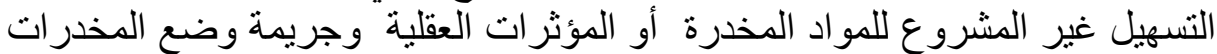

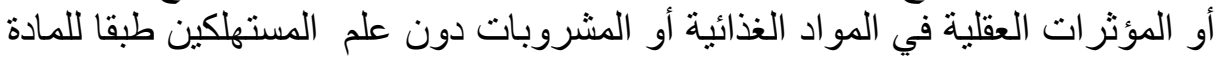

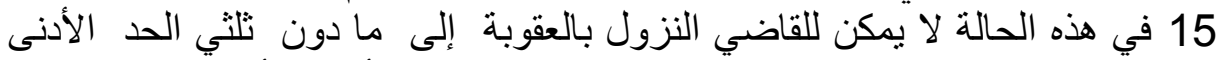

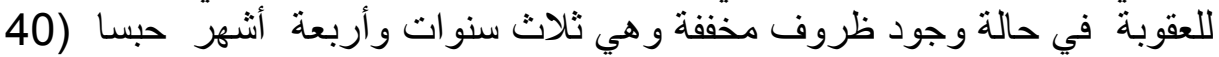

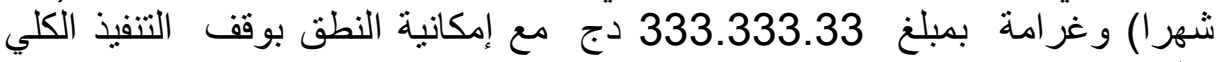
و الجزئي (29).

الفرع الثالث:الأعذار القانونية المقررة لجريمة استهلاك المخدرات: 
الأعذار القانونية : هي أسباب تخفيف وجوبي حصرها المشرع ونص المان عليها في

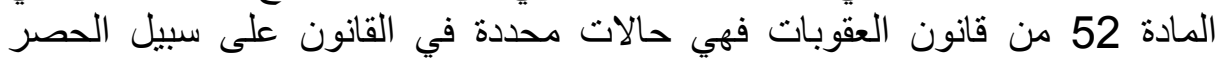

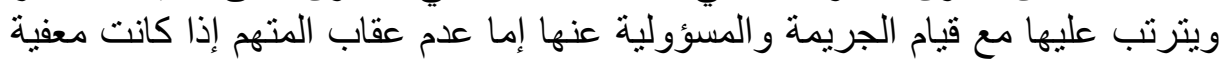
أو تخفيف العقوبة إذا كانت مخفقة.

وجريمة المخدرات كغيرها من الجرائم تطبق عليها الأعذار القانونية (المعفية

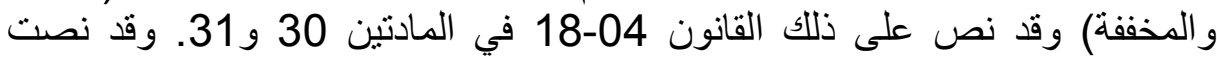

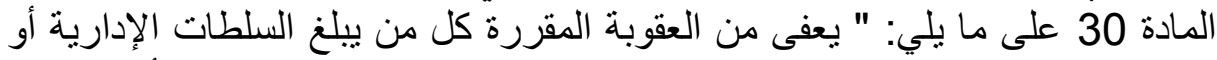

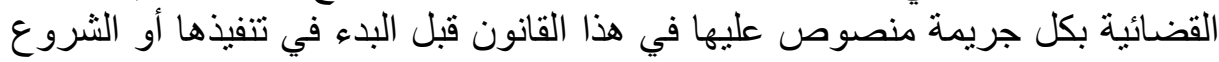

من خلال هذا النص يمكن أن نقول أن العذر المعفي من العقوبة بتعلق بو اقعة تتمثل

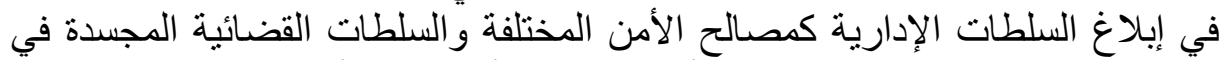

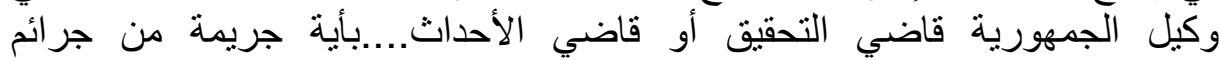

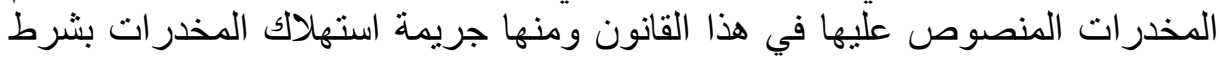

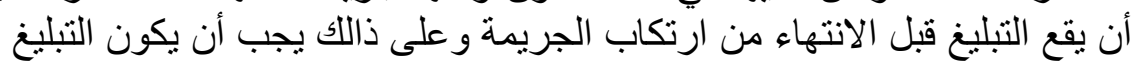

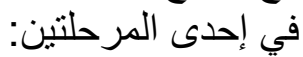
- - - قبل البدء في تنفيذ الجريمة بمعنى أثناء التحضير لها. -

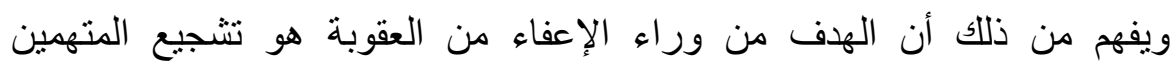

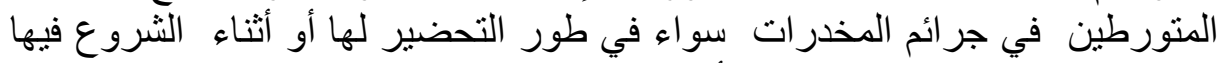

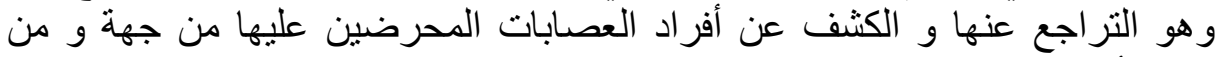
وجهه أخرى الوقاية من انتثار المواد المخدرة. (30)

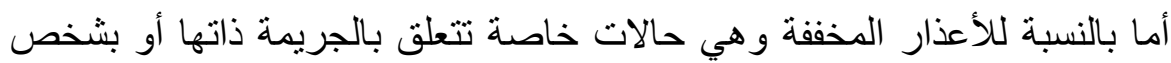

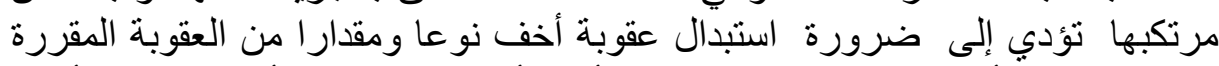

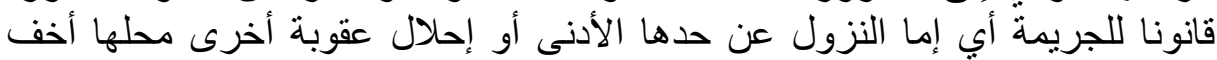

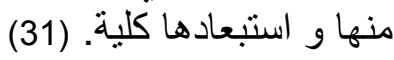

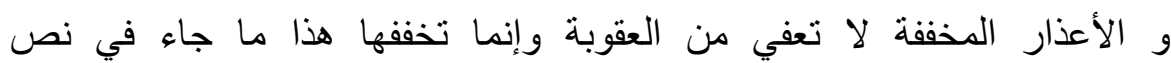

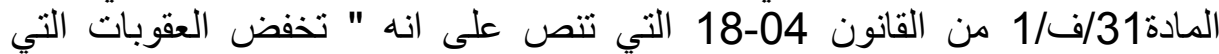

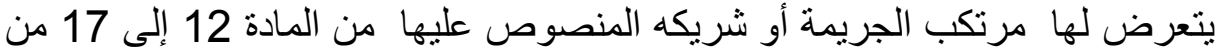

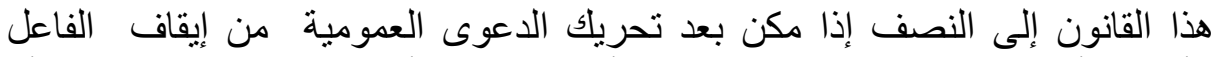

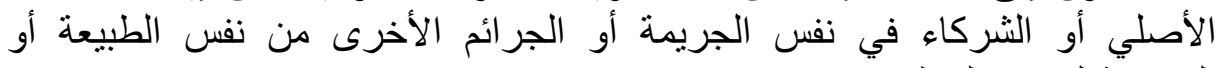

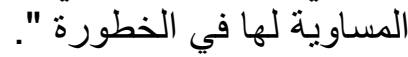

يفهر من هذا النص أن العذر المخف للعقوبة في جريمة استهلاك المخدرات

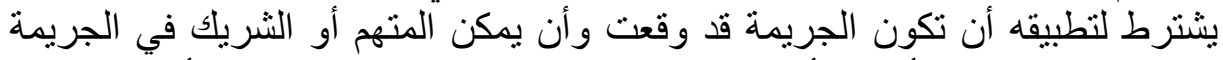
من إيقاف الفاعل الأصلي أو الثركاء في نفس الجريمة التي ارتكبها أو في جرائم التئ 
أخرى من نفس الطبيعة أو مساوية لها في الخطورة وأن تكون الدعوى العمومية قد

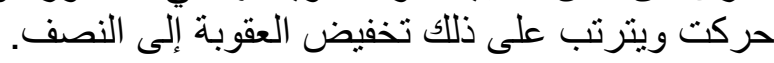

الفصل الثاني: تكريس مبدأ اعتناق التدابير الأمنية في جريمة استهلاك المخدرات

ظلت العقوبة لحقبة تاريخية طويلة الصورة الأساسية إن لم تكن الوحيدة للجزاء

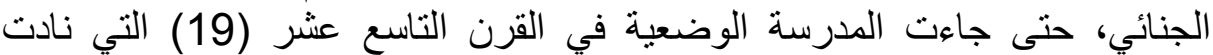

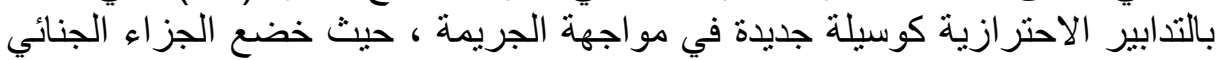

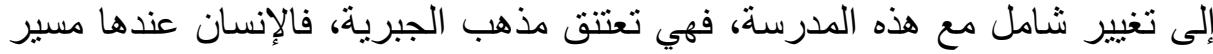

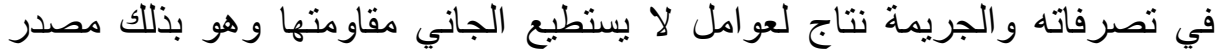

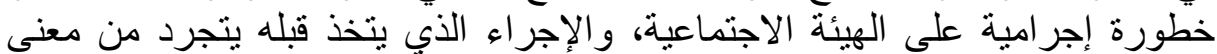

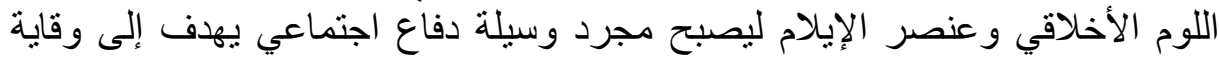
المجتمع من خطورة المجرم، وهذا الإجراء هو التدبير الاحترازي.

فالهدف من الجزاء عندها هو إصلاح حال الجاني مستقبلا دون محاسبته عما فيا

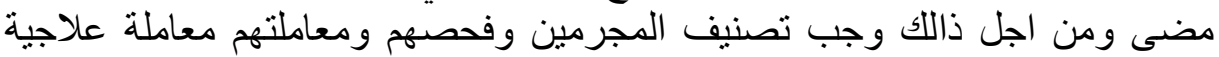
تهذيبية تبعا لنوع الخطورة الكامنة في كل مجرم منهم على حدة.

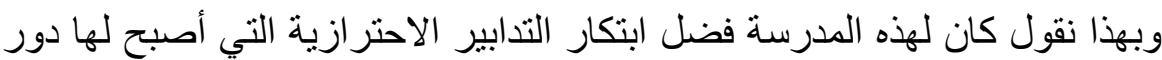

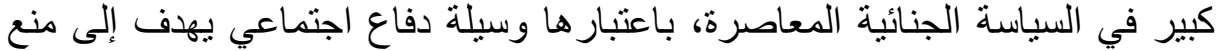

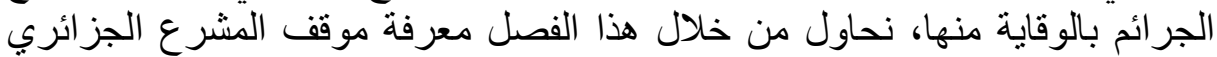

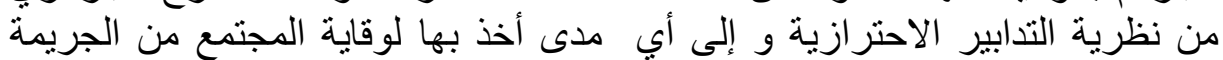
بصفة عامة وجريمة استهلاك المخدر ات بصفة التهة خاصة.

المبحث الأول: بدائل العقوبة المتخذة لجريمة استهلاك المخدرات

إذا كان من أهداف العقوبة الردع الخاص، فإن العقوبة ومن وراءها الأنظمة

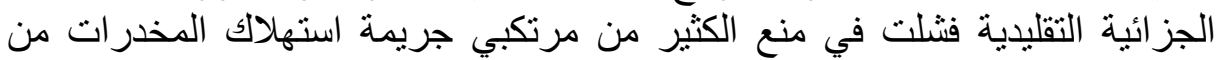
العودة إلى ارتكابها مما جعلهم مدمنين.

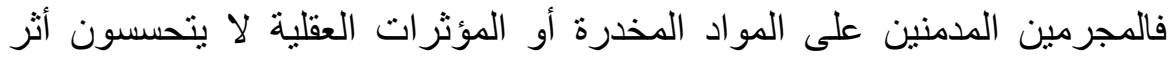

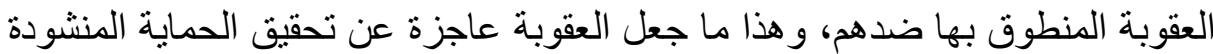

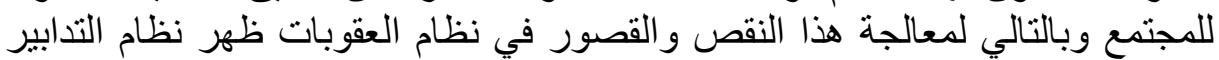

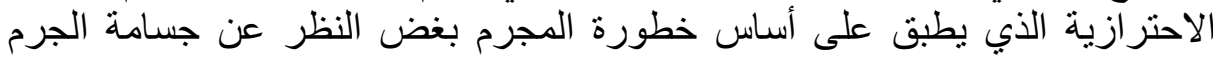

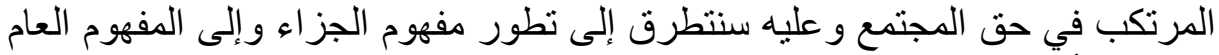
للتدابير الأمنية ( الاحتر ازية).

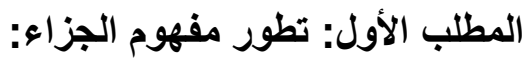

عرف الجزاء الجنائي تطورا في فترات متلاحقة ولكن في حدود العقوبة كوسيلة للسياسة الجنائية، على أن جاءت المدرسة الوضعية التي نادت بالتدابير الاحترازية 
كوسيلة جديدة فكان ذلك أعمق تغيير نوعي في تاريخ الجزاء الجنائي ولفهم ذاللك بوائة نبحث في مواضع قصور العقوبة وضرورة الأخذ بالتدابير وعلافة فئة التدبير بالعقوبة.

\section{الفرع الأول: قصور العقوبة وضرورة التدابير:}

يقر الققه الحديث على اختلاف اتجاهاته بعجز العقوبة في تقديم الحل الكامل

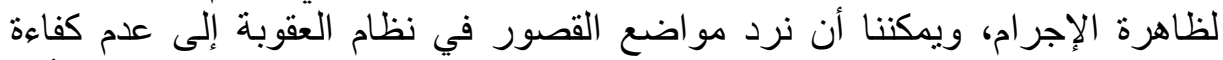

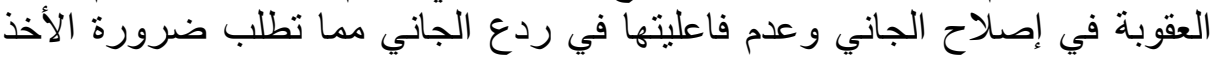

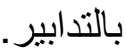

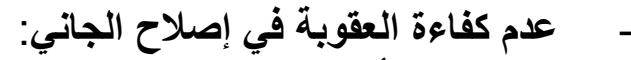

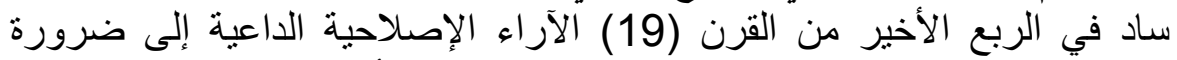

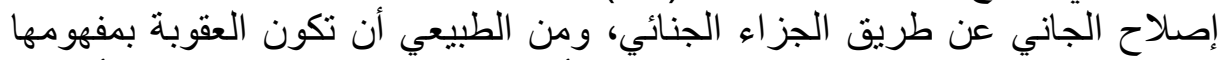

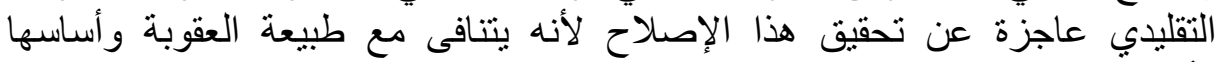
و وأهدافها.

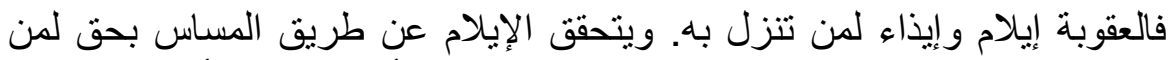

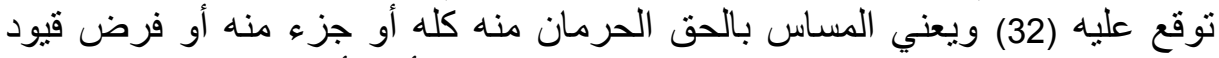

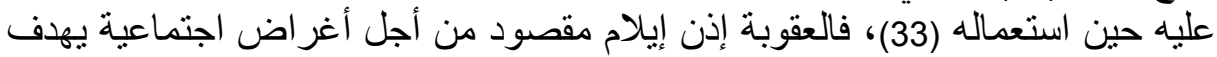

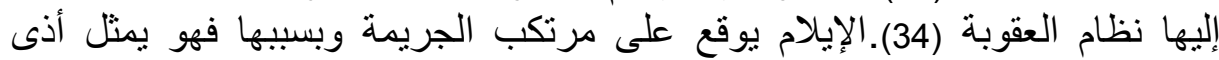

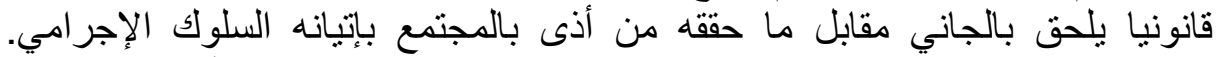

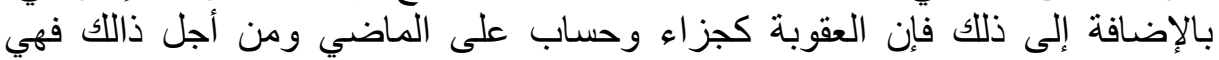

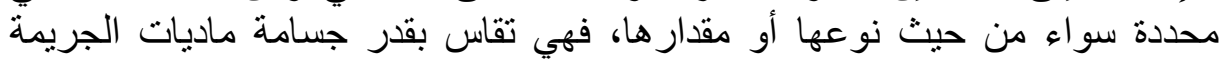

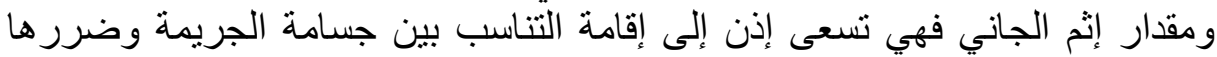
وبين العقوبة وشدتها تحقيقا لعدالة الجزاء الجئ الجنائي. و هذه المعاني و المبادئ جميعا لا لا

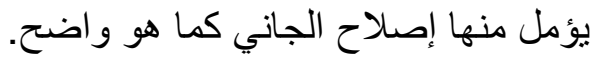

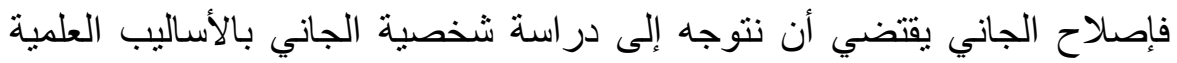

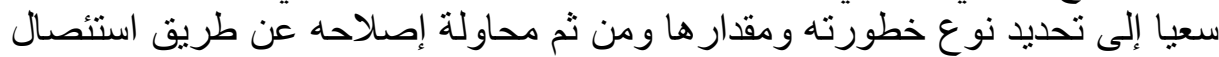

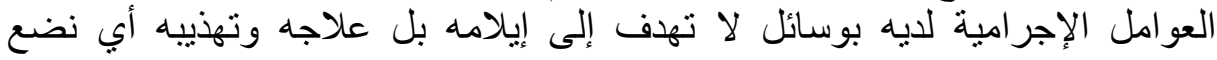

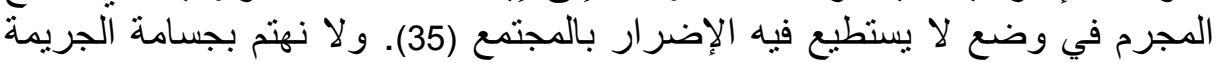

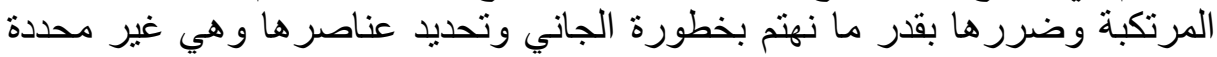
سلفا يترك تقديرها إلى تطور شخصية المحكوم عليه ومدى استجابته للوسائل

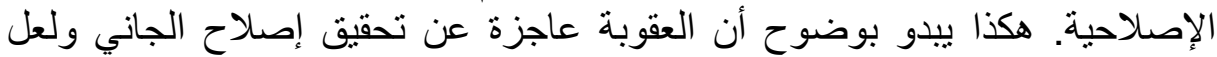

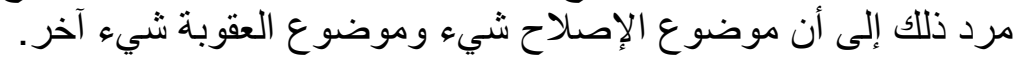

\section{عدم فاعلية العقوبة في ردع الجاني:}

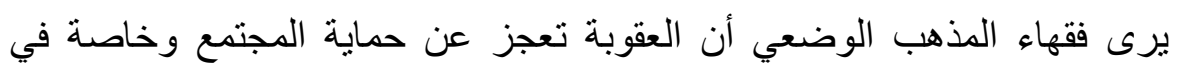
مواجهة بعض الفئات من المجرمين الخطيرين. فهي قاصرة عن التهني التطبيق في مواجهة 
المجرمين المجانين و هي غير فعالة في مواجهة المجرمين الثواذ و المدمنين.

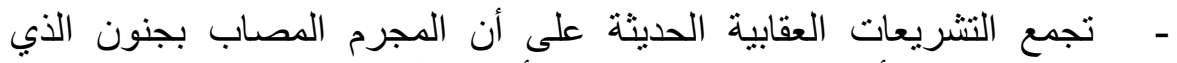

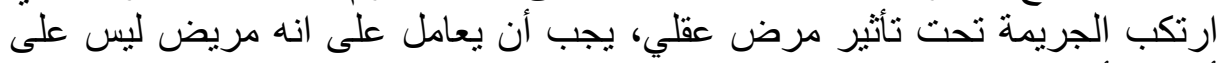

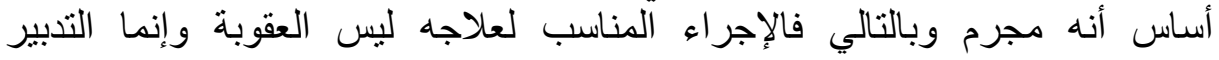

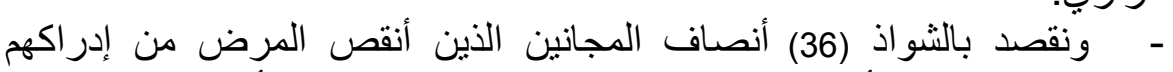

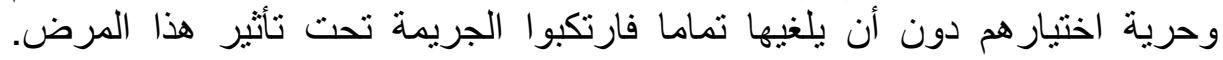

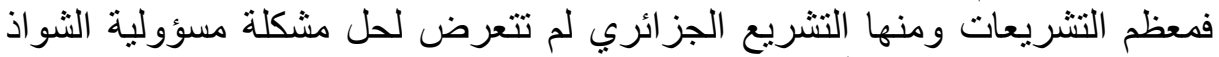

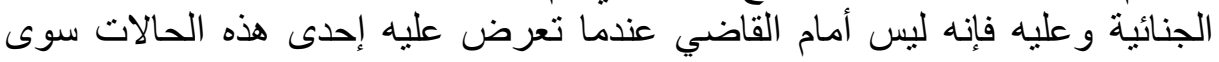

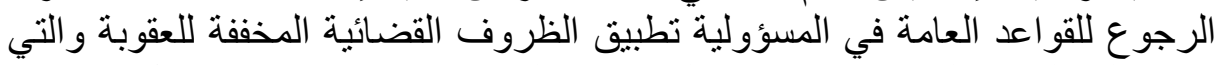

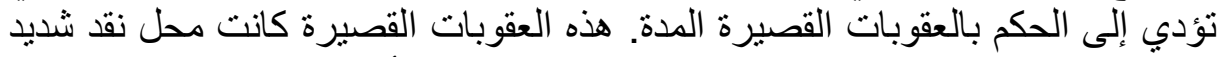

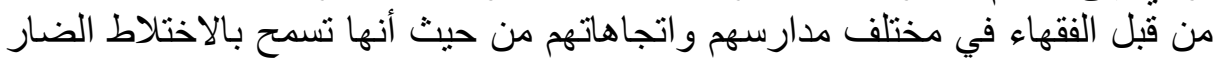

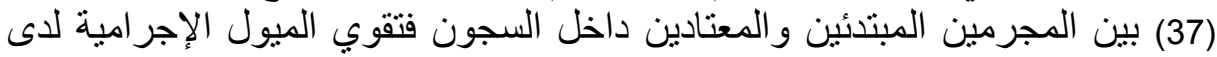

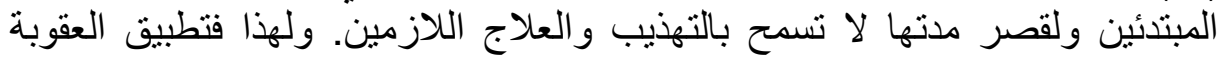

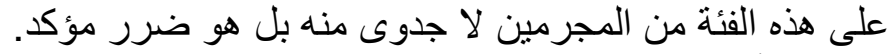

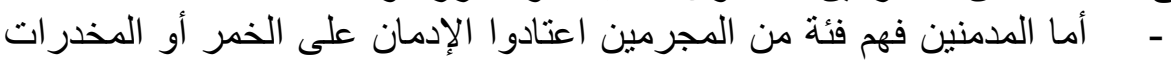
ويرتكبون الجر ائم بسبب هذا الإدمان.

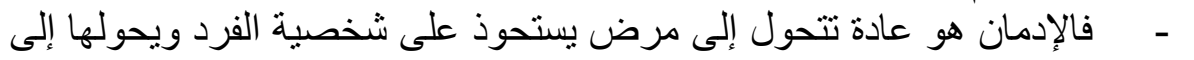

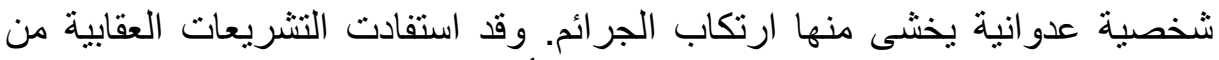

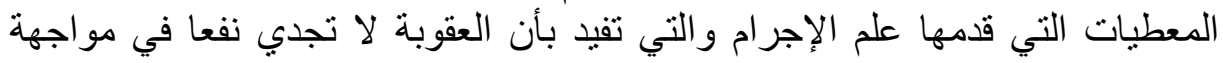

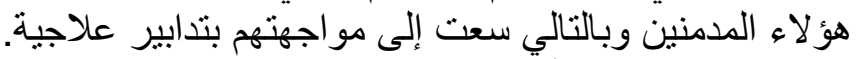

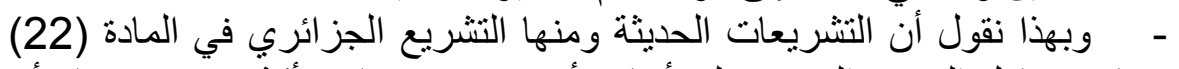

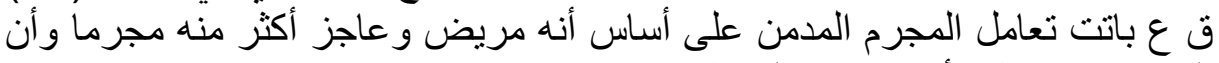

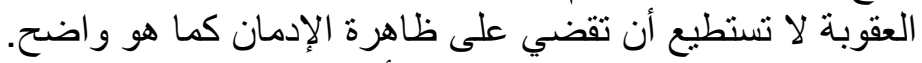

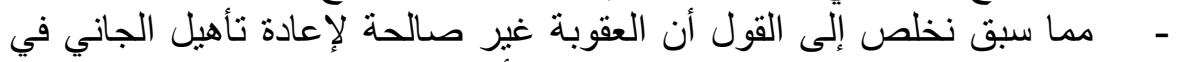

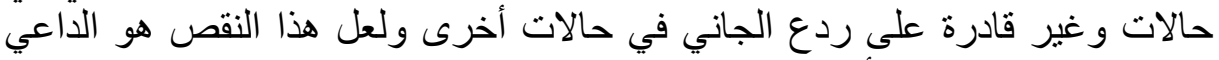

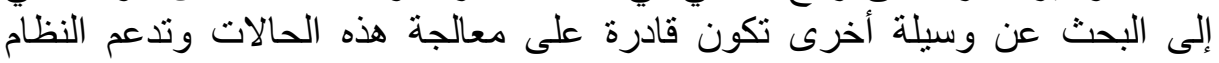
الجنائي، هذه الوسيلة هي التدابير الاحترازية.

\section{الفرع الثاني: علاقة التدبير بالعقوبة التهب}

تعد العقوبات والتدابير صورتين للجزاء الجنائي تعتمد عليهما السياسة الجنائية

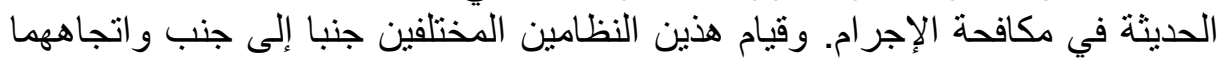

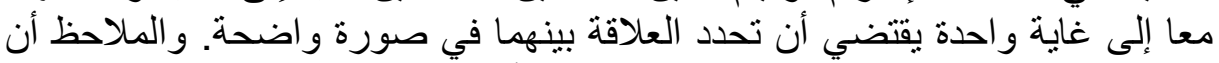

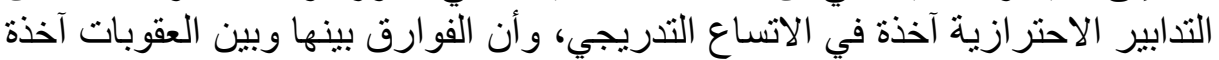

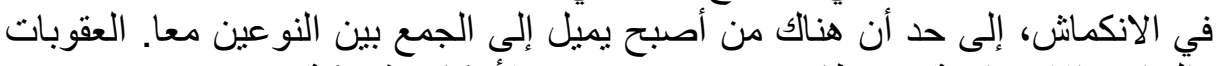
و التدابير الاحتر ازية في نظام توحيد (38) يخضع لأحكام مشتركة. 


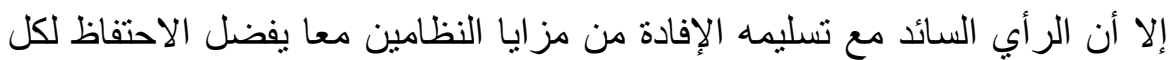

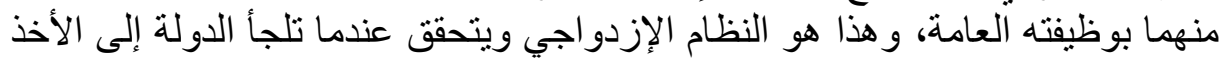

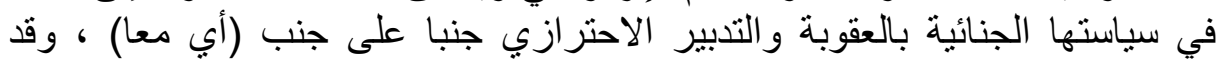

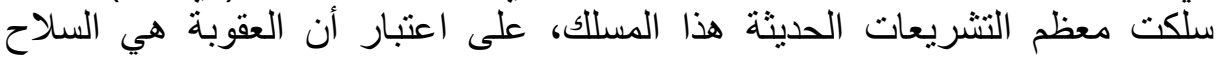

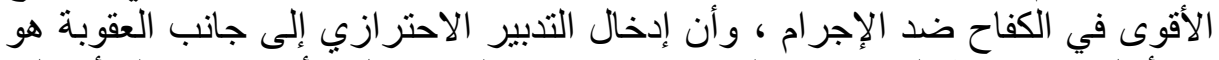

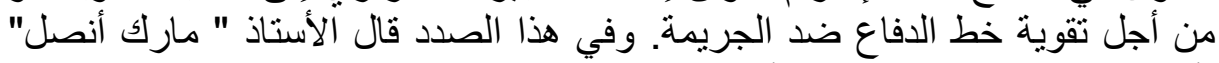

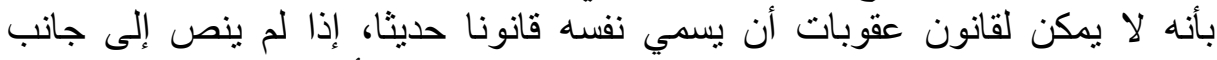

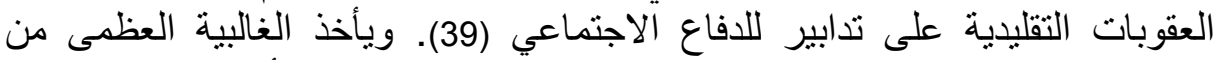

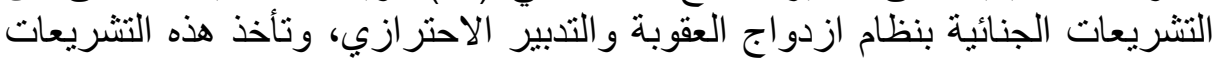

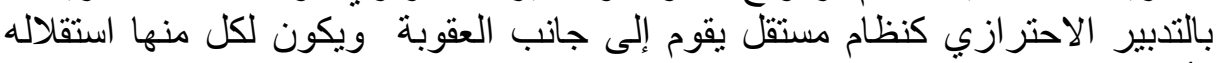

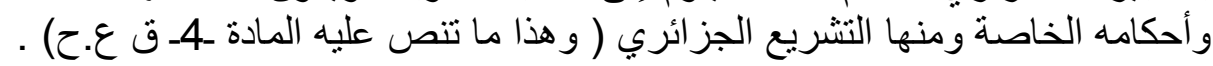

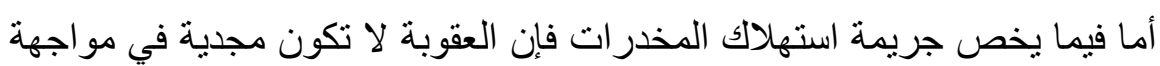

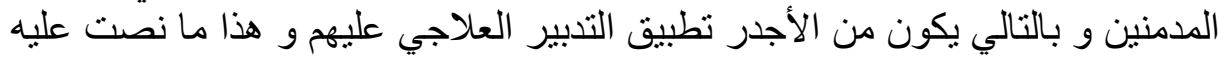

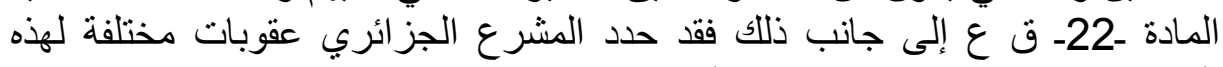

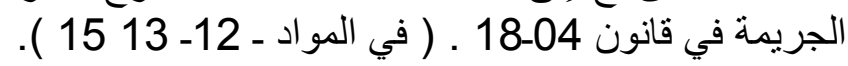

\section{المطلب الثاني : المفهوم العام للتدابير الأمنية ( أو الاحترازية )}

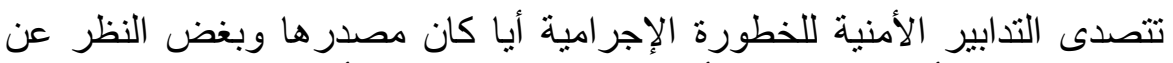

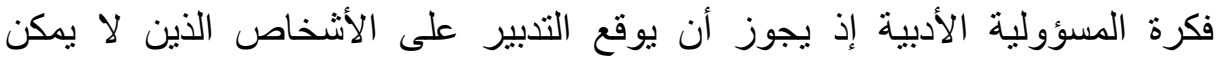

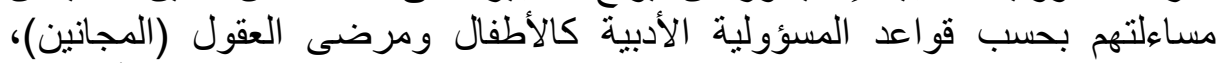

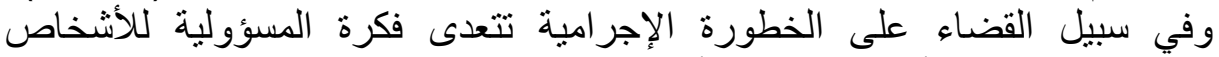

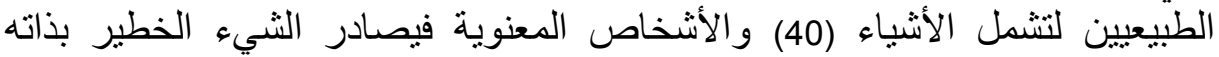

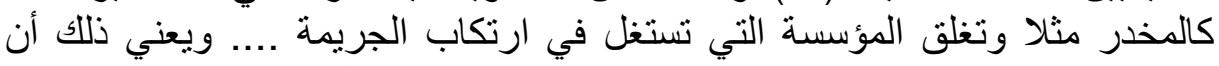

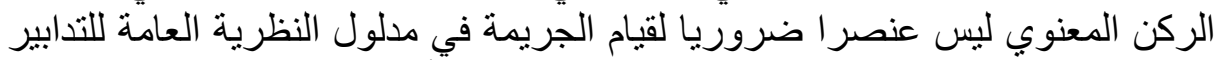
(41)، و عليه نتطرق إلى التعريف بالتدبير وخصائصه وأنو اعه.

\section{الفرع الأول : تعريف التدابيز الأمنية (42)}

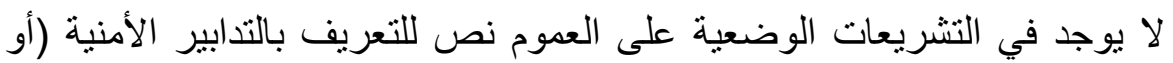

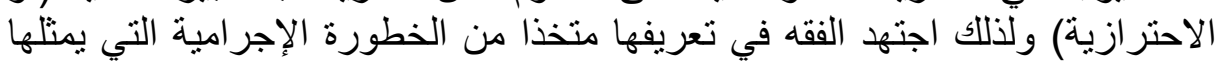
الجاني مناط للتعريف بها.

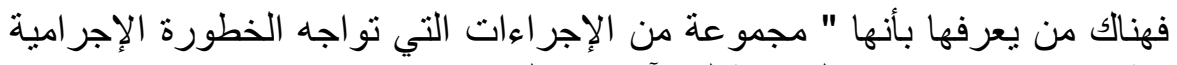

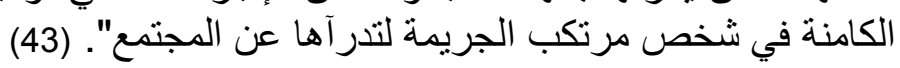

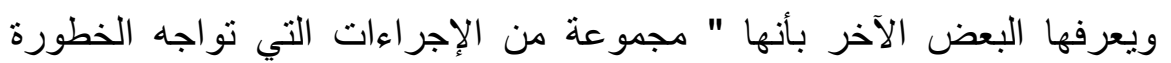

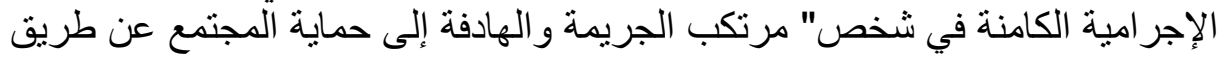
منع المجرم من العودة إلى ارتكاب جر ائم جديدة". (44) 
ولم تخرج التعريفات الأخرى في الفقه العربي (45) عن هذا المفهوم إذا أنها

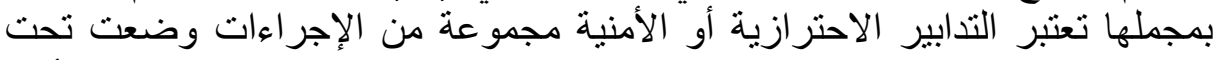

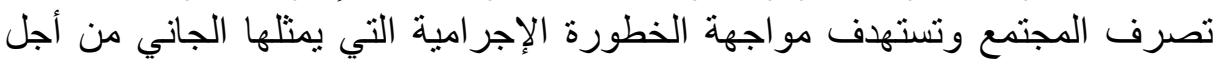
وقاية المجتمع من الإجر ام.

\section{الفرع الثاني : خصائص التّبير:}

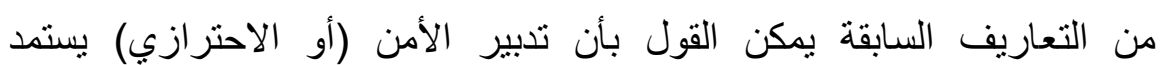

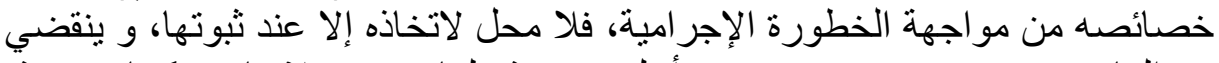

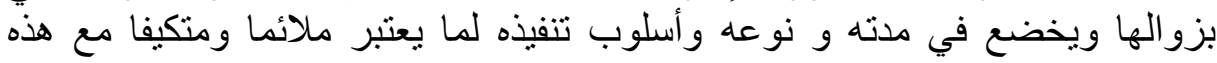
الخطورة وتطور ها.

وحيث أن طبيعة الخطورة الإجر امية لدى الفرد متتوعة و أسبابها متشعبة و لا يمكن

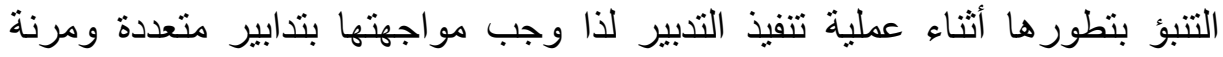

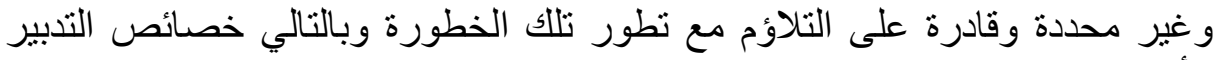

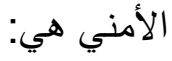

ـ متجرد من الفحوى الأخلاقي: يتجه التدبير إلى إبطال مفعول الخطورة الإجر امبة التهاية

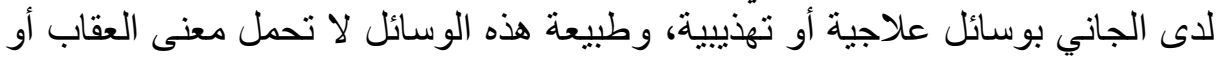
التناسب مع خطأ سابق بل التوخي من جريمة محتملة. ـ المدة الغير محددة للتدبير : يكاد يجمع الفقه على أن التدابير غير محددة المدة المدئ

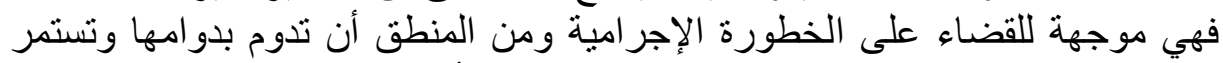

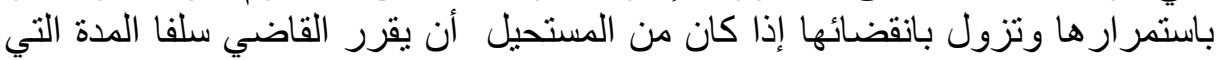

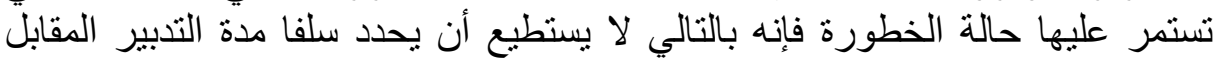

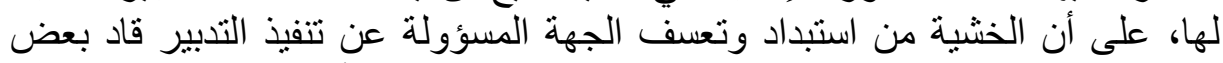

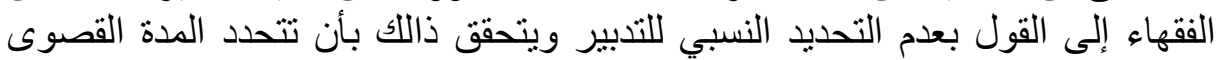

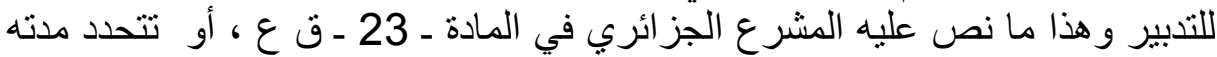

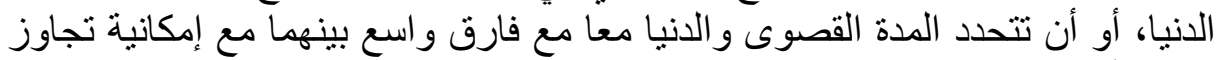

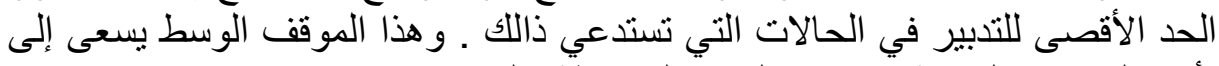

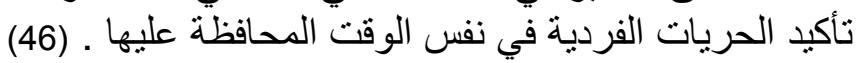

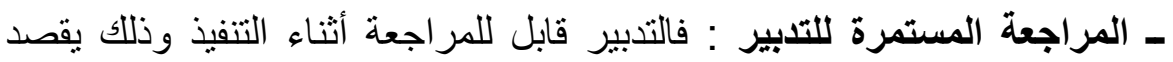

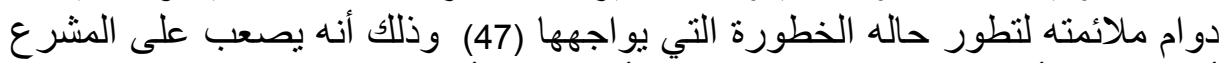

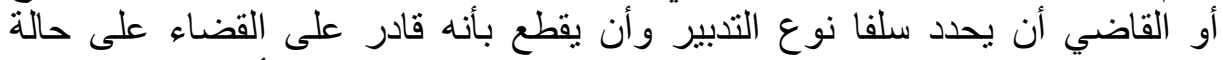

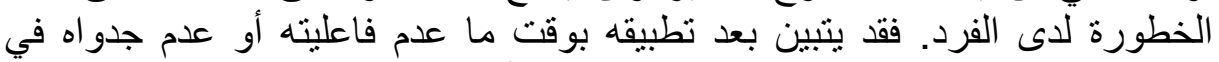

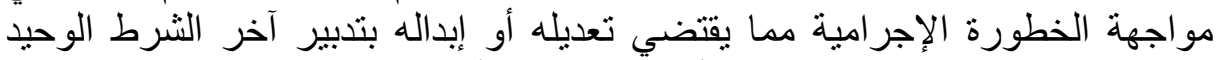
المتطلب في التدبير الجديد هو كونه أكثر صلاحية وأكثر فعالية في مواجهة الخطبة الخطورة. 
فإذا كان التدبير ينزل بناءا على فحص شخص الفرد الخطر فإنه أيضا ينتهي

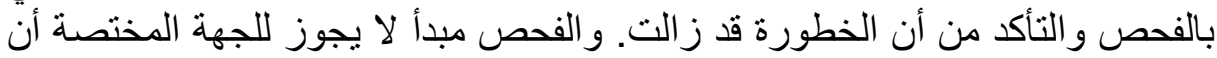

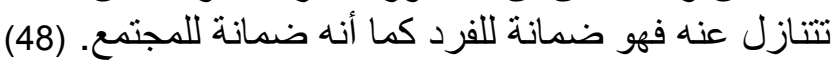

الفرع الثالث: أنواع التدابير

لجأ الفقه إلى معايير مختلفة لتقسيم التدابير، فمن حيث أهدافها تقسم إلى تدابير علاجية وتدابير تهذيبية، وقد أخذ المشرع الجزائري بهذا التقسيم، حيث نص على التى

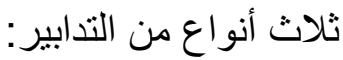

01- الحجز القضائي في مؤسسة نفسية بالنسبة للمجانين و المختلين عقليا .

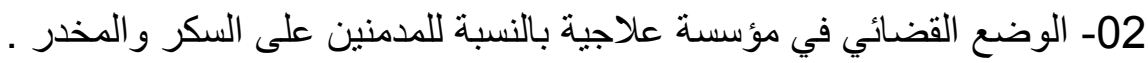
03- التدابير الخاصة بالأحداث أو الأطفال.

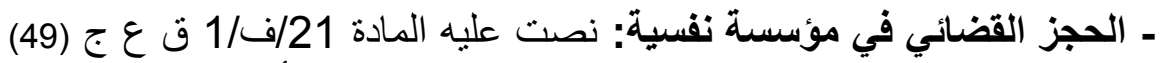

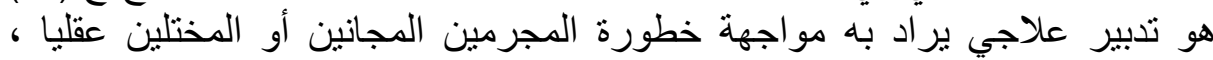

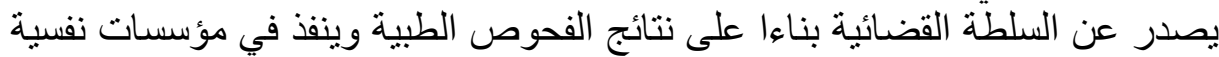

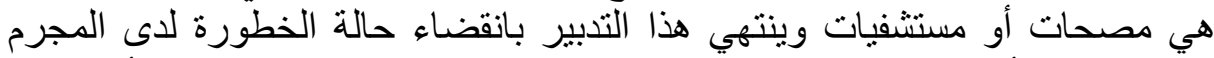
المجنون وهو أمر يترك تقديره للقضاء الذي يستعين بتقارير طبية في هذاء الثأن.

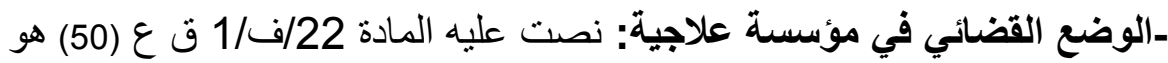

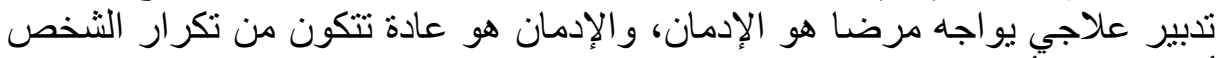

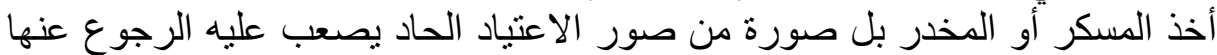
أو التخلص من تأثثيرها، وهذه العادة تتحول إلى مرض الته يفقد الإنسان سيطرته على التى

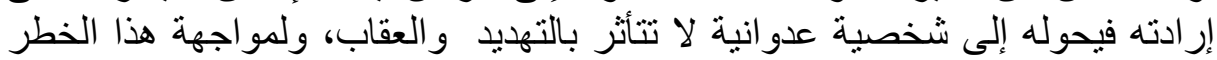

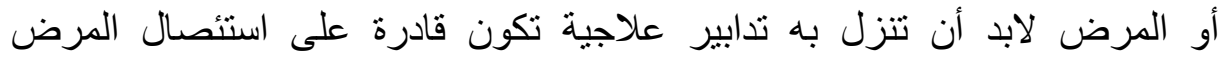

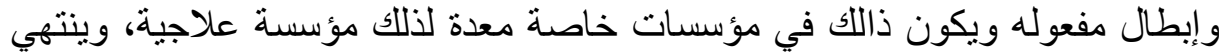

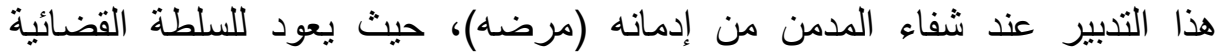
المشرفة على تنفيذ التدبير أمر تقديره بناء على التقارير الطبية بهذا الثنأن.

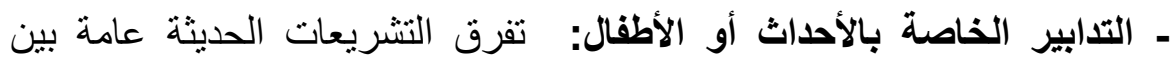

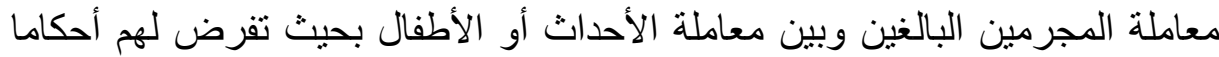

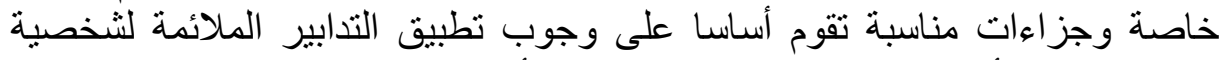

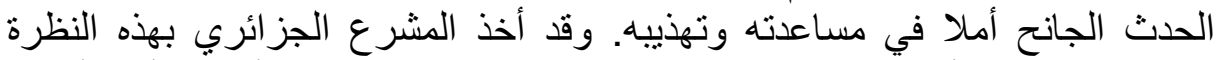
الحديث لمعاملة الأحداث في المادة 49 ق ع ع ج (51) التي تقنم الأحداث أو أو الأطفال

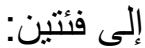

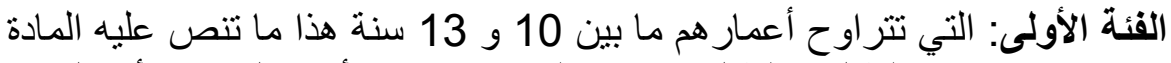

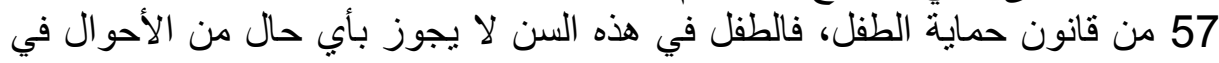


التشريع العقابي الجزائري أن يحكم عليه بعقوبة لامتناع مسؤوليته الجنائية مطلقا

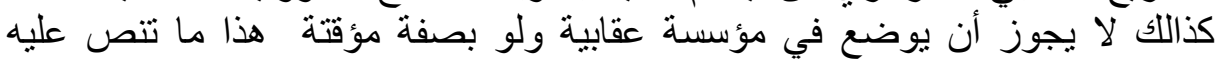
المادة 58/ف/1 من قانون حماية الطفل و لا يكون إلا محلا لتدابير الحماية والتهذيب

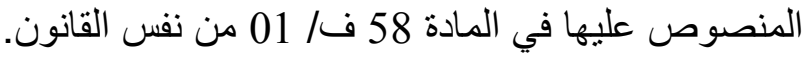

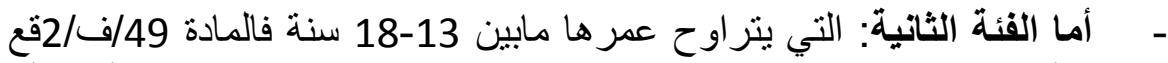

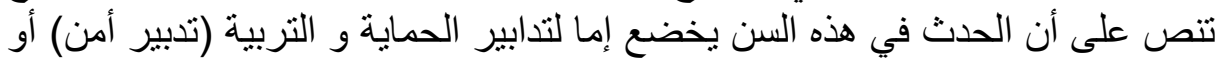

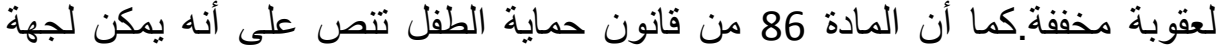

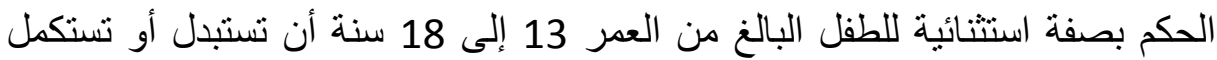

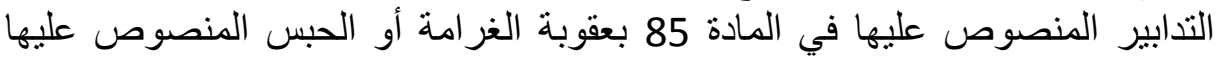

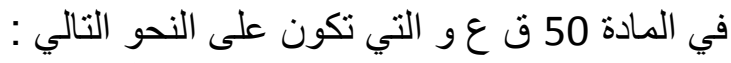

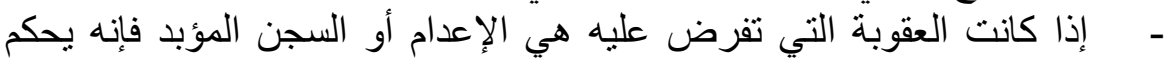

$$
\text { عليه بعقوبة الحبس من } 10 \text { إلى } 20 \text { سنة. }
$$

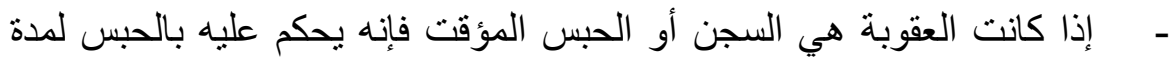

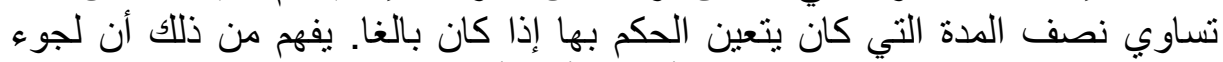

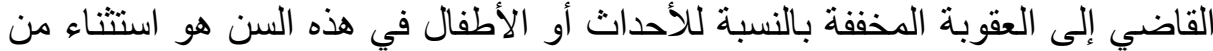
الأصل العام وهو تطبيق تدابير الحماية والتهذيب. يطبق العقوبة المخففة إذا قدر

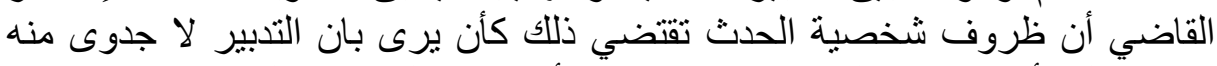

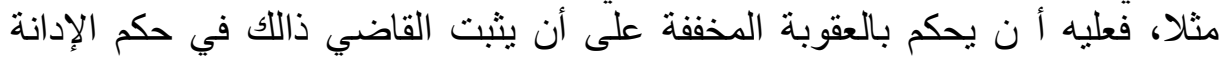
و هذا ما يجعل للعقوبة دورا تربويا يستهدف إصلاح حالة الحدث وتقويمها.

المبحث الثاني: السياسة الوقائية والتعاون الدولي في مواجهة ظاهرة استهلاك المخدرات

إن مشكلة إساءة استعمال المخدرات و المؤثرات العقلية أصبحت تمثنل خطرا

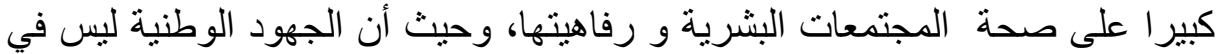

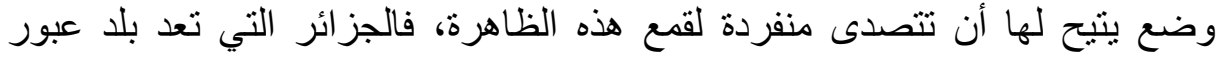

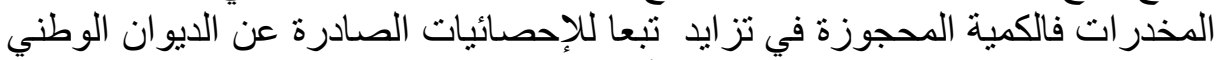

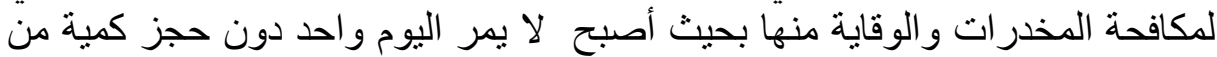

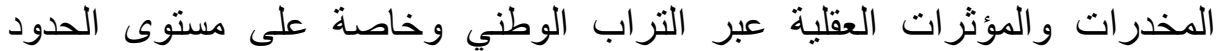

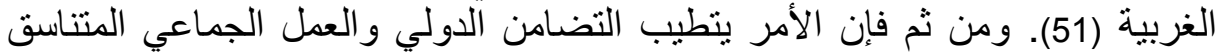

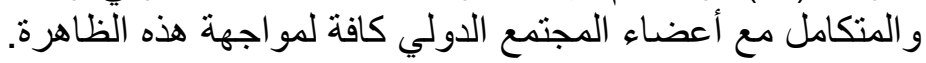

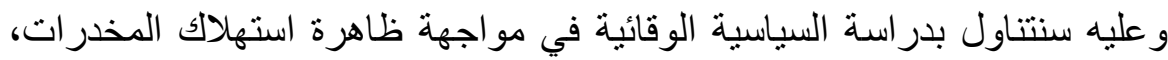
والجهود المبذولة في مكافحة جريمة استهلاك المخدرات على المستوى الدولي و والوطني. المطلب الأول: السياسة الوقائية في مواجهة جريمة استهلاك المخدرات. 


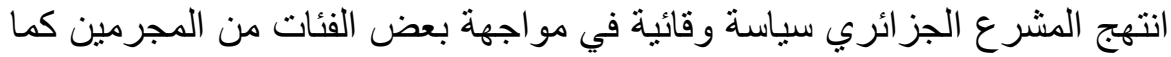

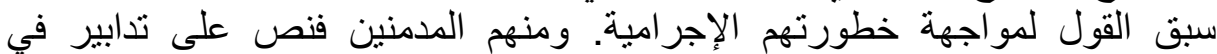

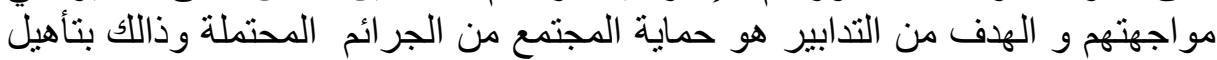

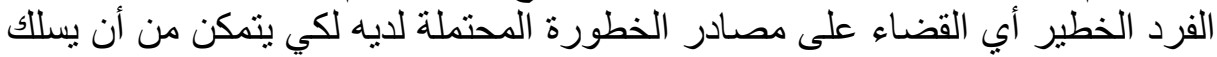

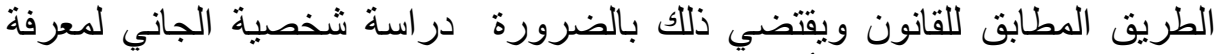

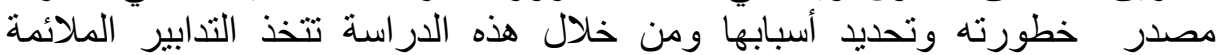

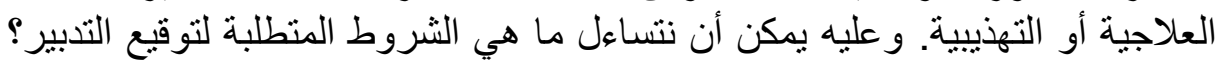

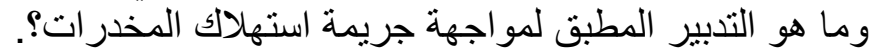

\section{الفرع الأول : شروط تطبيق التدبير :}

فالثروط الموضوعية العامة الواجب نو افر ها من أجل إنزال التدبير يحصر ها الفقه

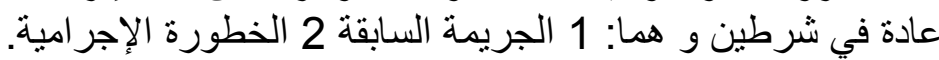

1. الجريمة السابقة: فهذا الثرط يقول بها الرأي الغالب في الفقه (52) و تقره

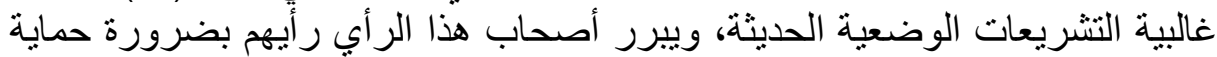

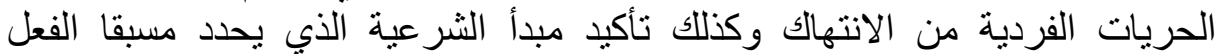

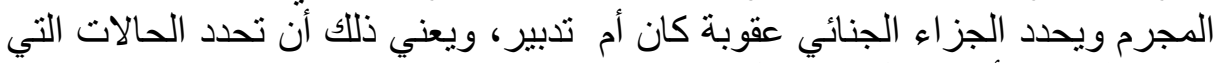
يجوز للقاضي أن يتدخل فيها قبل ارتكاب الجريمة تحديدا دقيقا مما يكسبها الثيان الثرعية.

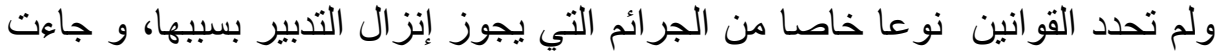

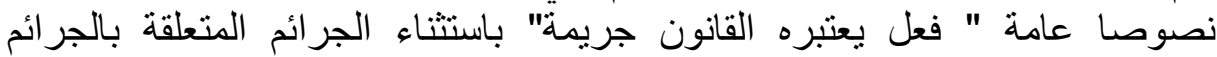

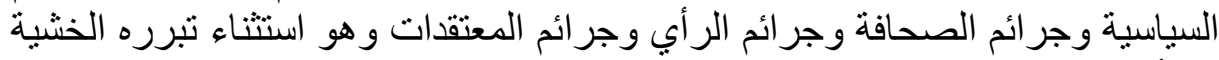

من أن تستخدم السلطات العامة التدبير للكيد بخصومها السياتئ السيبين. (53)

2.

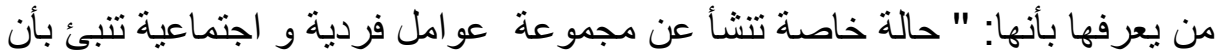
الثخص الذي ارتكب فعلا يعد جريمة من المحتمل أن يرتكب في المستقبل أفعالا

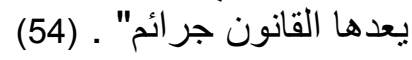

و هناك من يعرفها بأنها " احتمال ارتكاب المجرم لجريمة تالية “، (55)

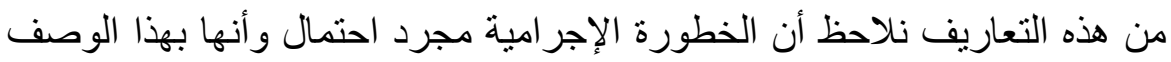
نوع من التوقع منصرف إلى المستقبل وموضوع هذا التوقع هو جريمة تصدر عن نفس الشخص الذي ارتكب جريمة سابقة.

ويصعب تحديد الخطورة الإجرامية لأنها من الأمور التي تتعلق بذاتية الإنسان

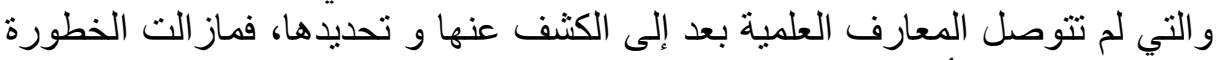

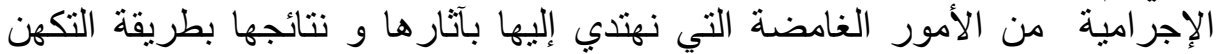

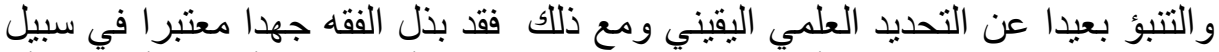

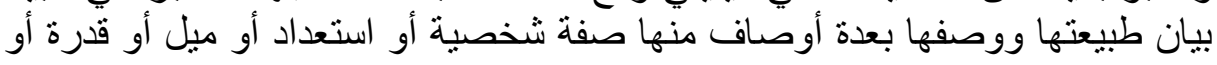


أهلية أو خصيصة لارتكاب الجريمة.

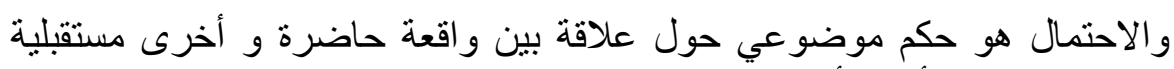

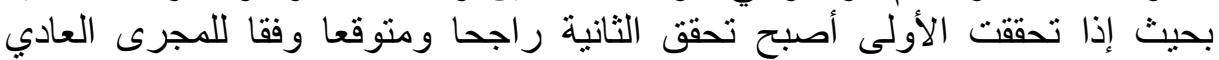
لالأمور.

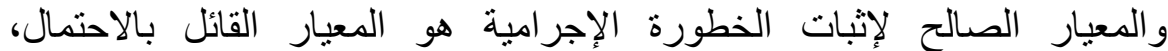

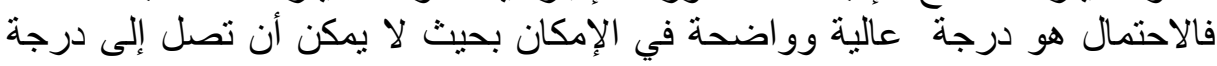

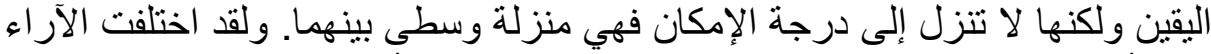

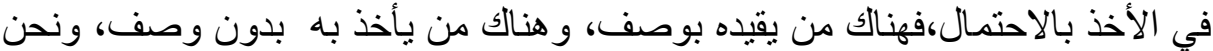
نرى أن الأخذ بالاحتمال بدون وصف هو الجدير بالإتباع فهو المعيار المرن الذي يترك للقاضي القدرة على الاستخلاص و والتقدير.

الفرع الثاني: التدابير الأمنية المقررة لجريمة استهلاك المخدرات حدد قانون العقوبات الجزائري تدابير الأمن في المادة -19- منه في : 1.

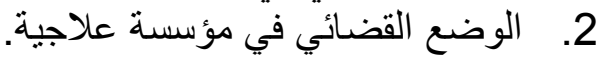

وحددت المادة -22- ق.ع المقصود بالوضع القضائي في مؤسسة علاجية بأنه

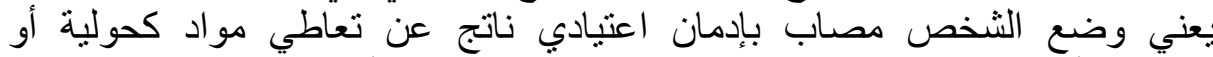

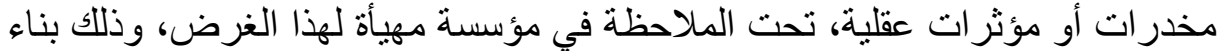

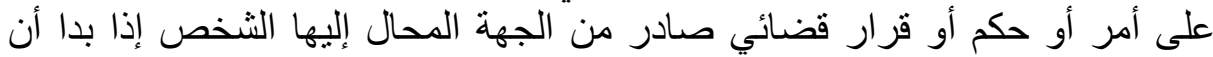

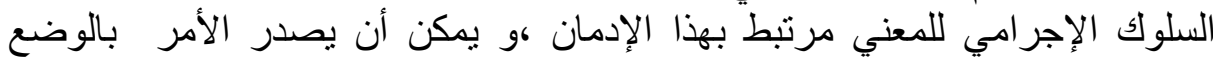

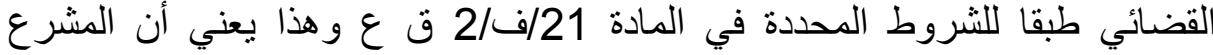

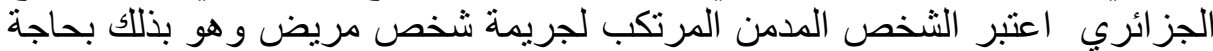

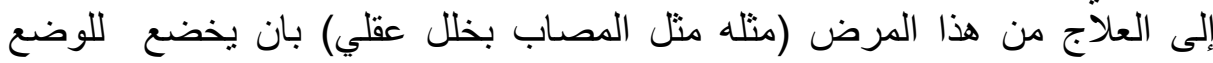
القضائي في مؤسسة علاجية.

وبالرجوع إلى القانون 18-184 المتعلق بالوقاية من المخدرات و المؤثرات العقلية نجد المادة 02 منه تحدد معنى الإدمان بقولها: "الإدمان: حالة تبعية نفسانية أو تبعية التهان

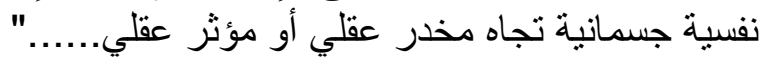

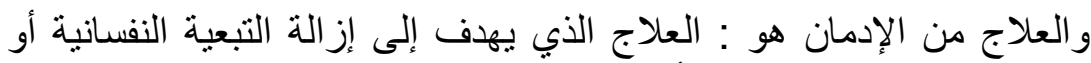
التبعية النفسية الجسمانية تجاه المخدر أو مؤثر عقلئي.

وما يلاحظ على هذا القانون أنه يتضمن مصطلحي الوقاية والعلاج وقرر في هذا

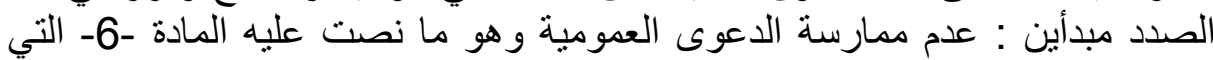

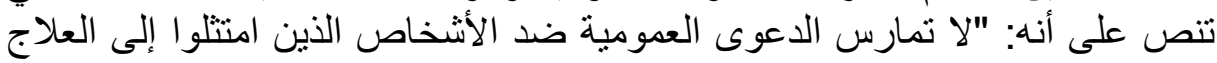
الطبي الذي وصف لهم لإز الة التسمم وتابعوه حتى نهايته. 


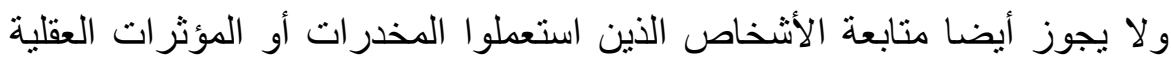

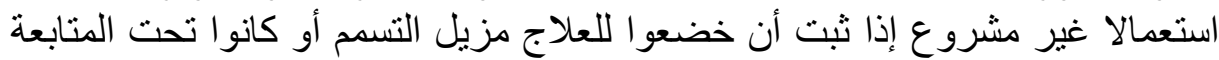
الطبية منذ حدوث الوقائع المنسوبة إليهم...".

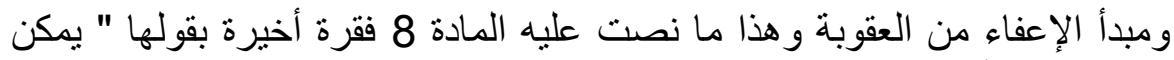
للجهة القضائية أن تعفي الشخص من العقوبات المنصوص عليها في المادة 12 من

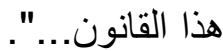

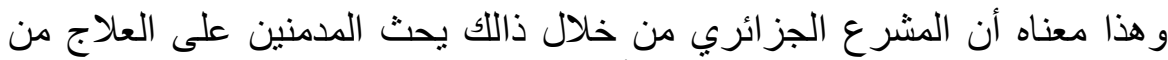

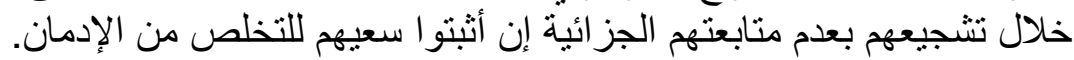

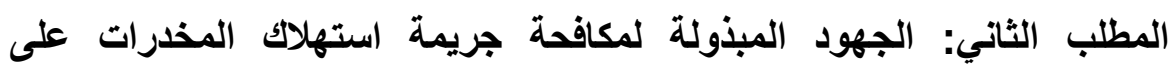
المستوى الاولي و الوطني

مما لا شك فيه أن آفة المخدرات أصبحت تشكل مصدر قلق سواء بالنسبة

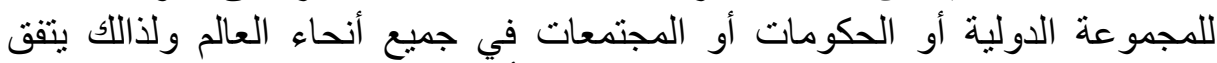

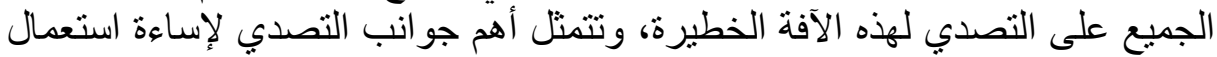

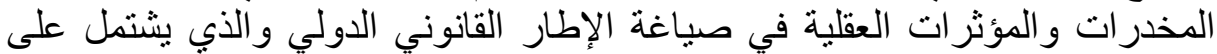

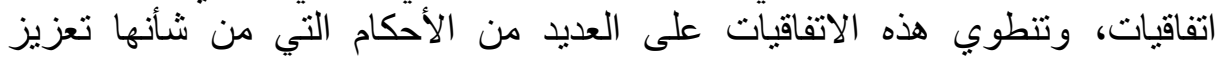

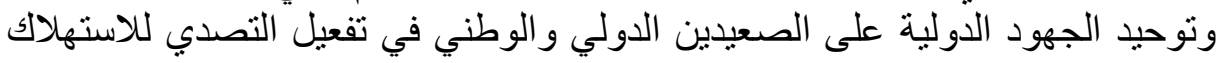
غير المشروع للمخدرات و المؤثرات العقلية.

الفرع الأول: الاتفاقيات الدولية لمكافحة جريمة استهلاك المخدرات:

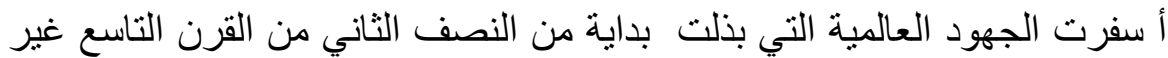

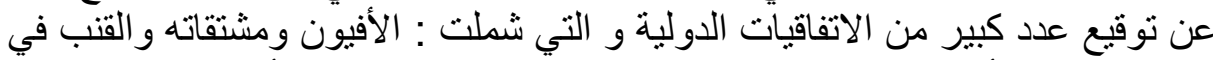

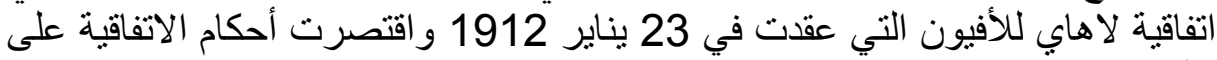
الأفيون ومشتقاته ثم اتفاقية جنيف لعام 1925 والتي التي عقدت في 9 فبراير 1925

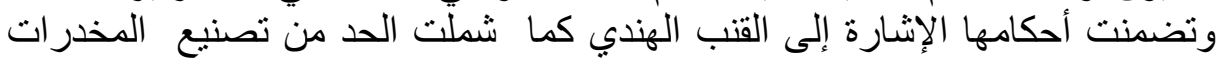
وتوزيعها وقصر استخدامها على الأغراض الطبية و والعلمية كاتفاقية جنيف لعام 1931 و التي عقدت في 13 يوليو 1931.

كما شملت الحد من الاتجار غير المشروع في المخدرات واتفاقية جنيف لعام 1936و التي أبرمت في 26 يوليو 1936 بقصد الاتجار غير المشروع للمخدرات. كما شملت المواد التخليقية في بروتكول باريس لعام 1948 المنعقد في 19

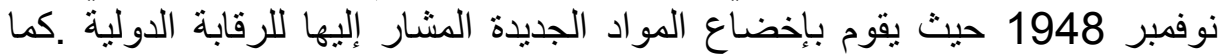
شمل تنظيم الزراعة المخدرة، كبروتكول نيويورك لعام 1953 و والذي أبرم في 13

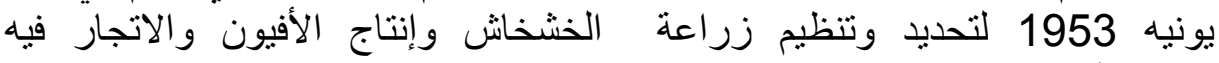




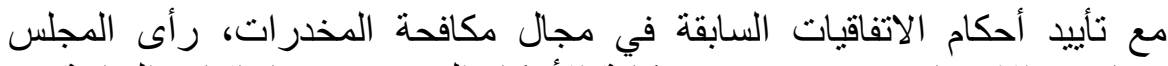

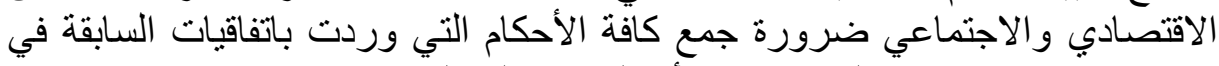

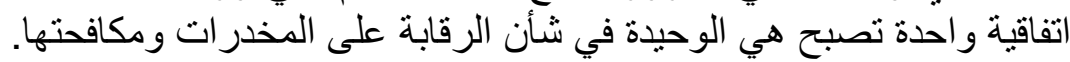

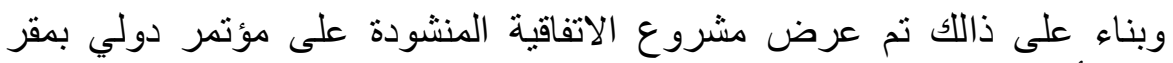

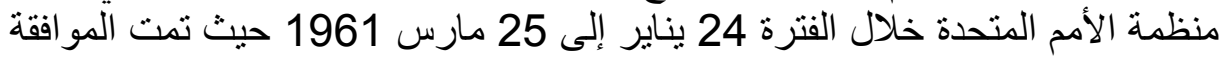

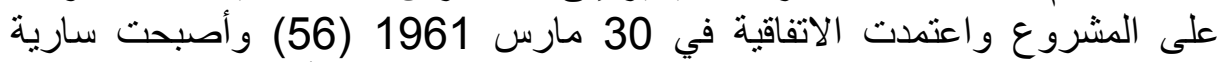

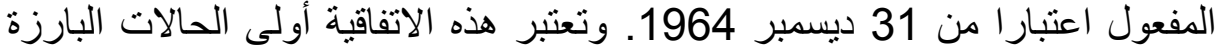

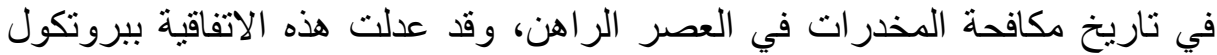

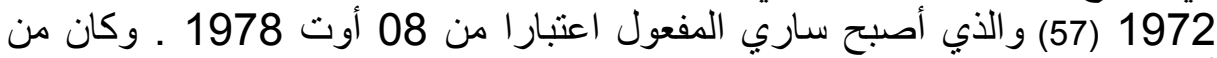

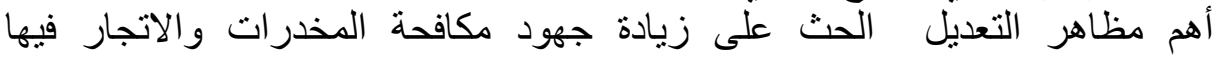
و استهلاكها، وضرورة توفير العلاج للمدمنين وتأهيلهم إلى جانب العقودة العهات الموجودة.

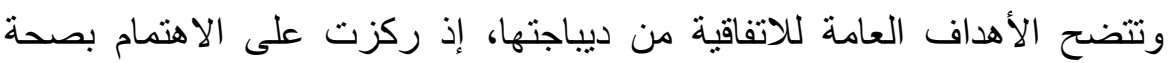

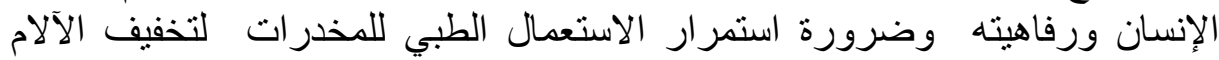

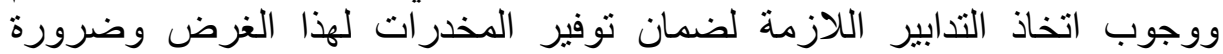

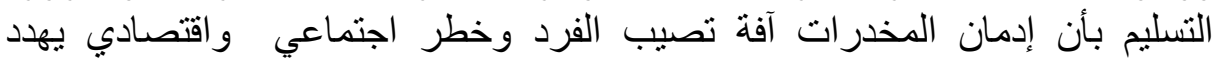

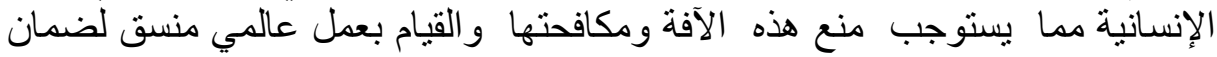

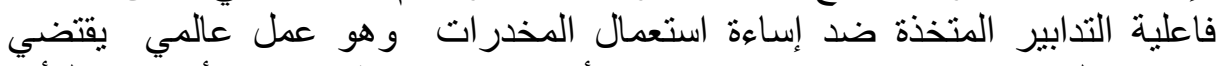

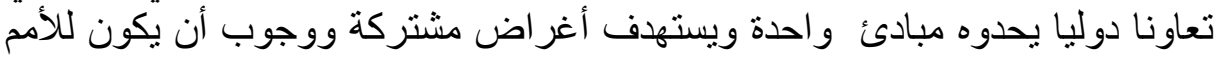

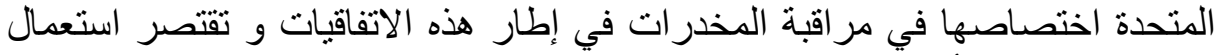

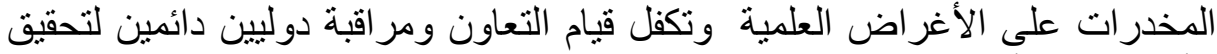
الأغر اض والأهداف المشار إليها. (58)

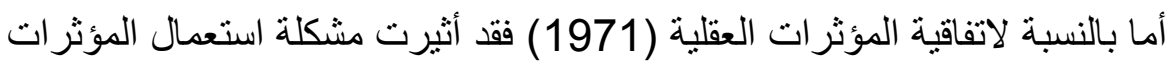

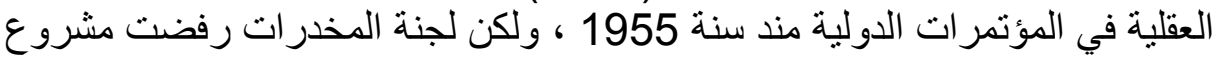

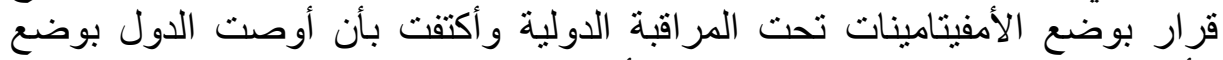

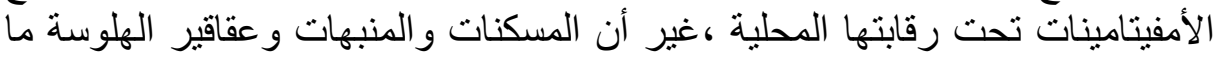

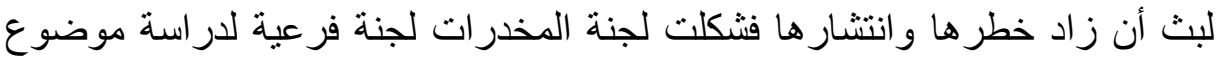

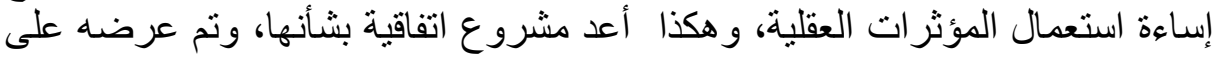

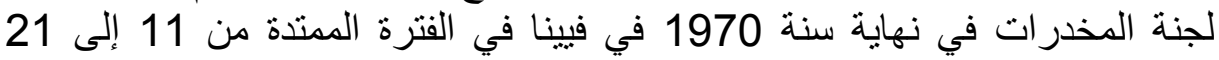

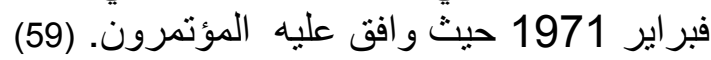

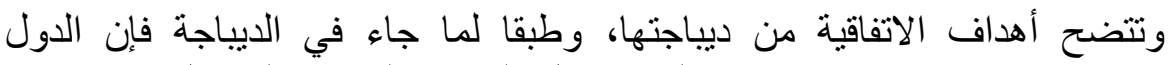

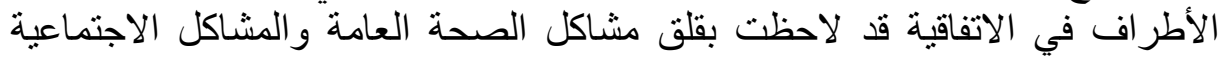

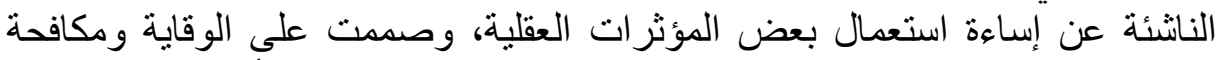

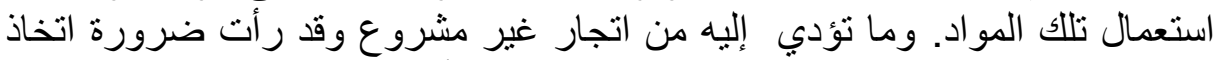

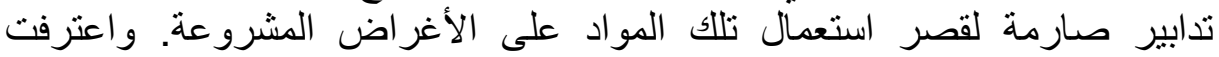


باستعمال المؤثرات العقلية للأغراض الطبية والعلمية، وأنه ينبغي ألا يقيد الحصول

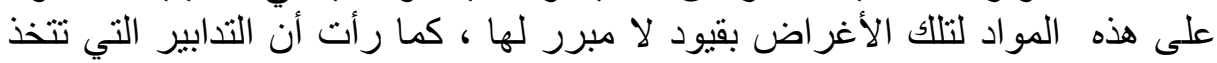

للحيلولة دون إساءة استعمال تلك المواد تقنضي عملا منسقاو وعالمي النطاق (60)

\section{الفرع الثاني:الجهود الوطنية لمكافحة جريمة استهلاك المخدرات}

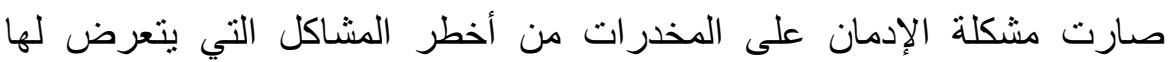

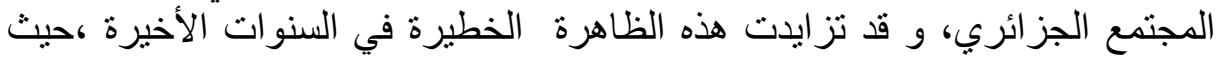

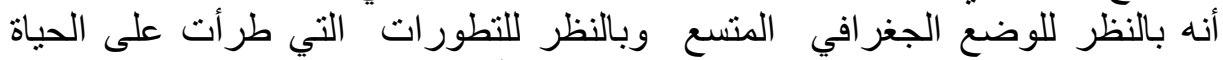

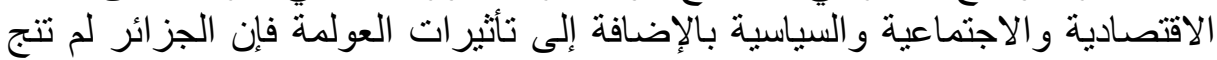

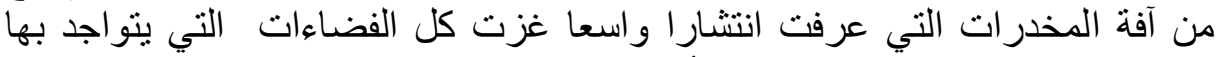

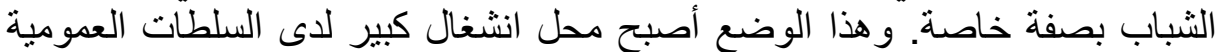

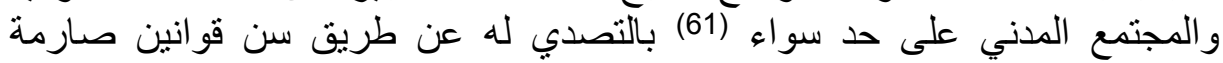

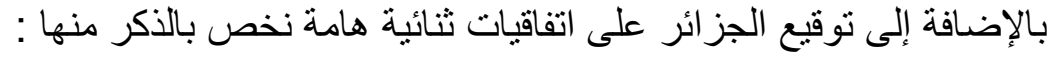

$$
\text { - - الاتفاقية الجز ائرية الإيطالية لسنة } 1999
$$

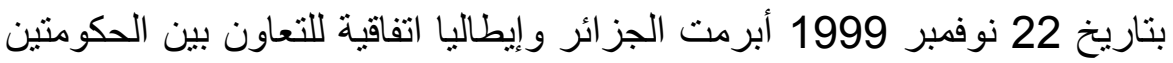

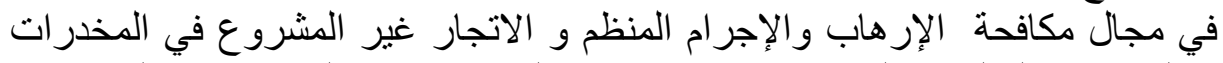

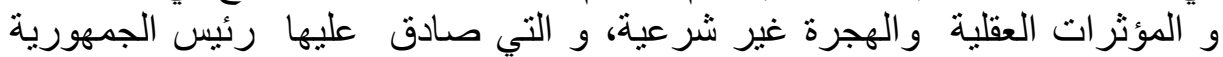
بموجب مرسوم رئاسي تحت رقم

9-77 من الدستور · (62)

فالمادة الأولى من الاتفاقية فقرة (ج) تضمنت عدة تدابير تتمثل في تبادل المعلومات

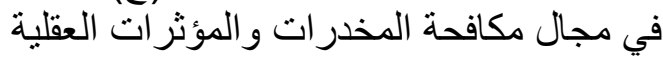

$$
\text { - الاتفاقية الجزائرية الفرنسية لسنة } 2003 .
$$

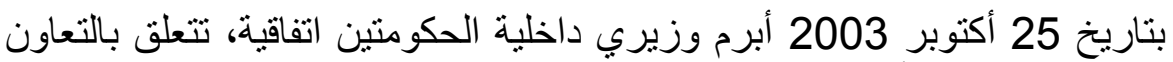

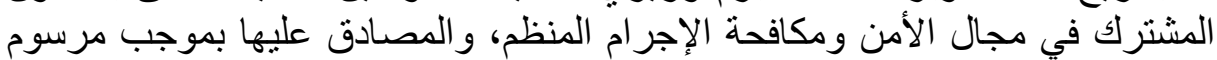

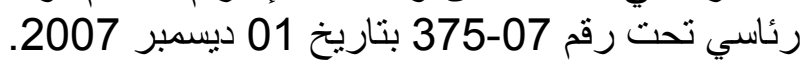

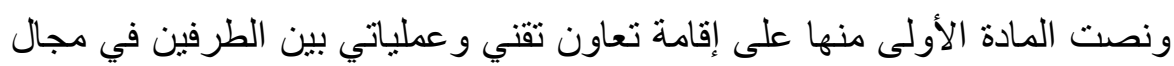

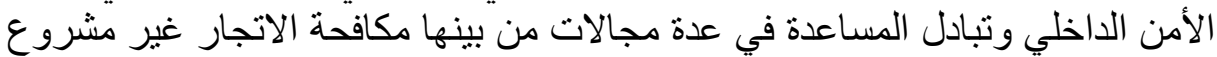

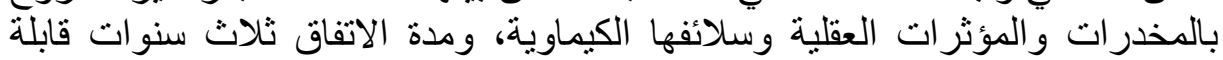

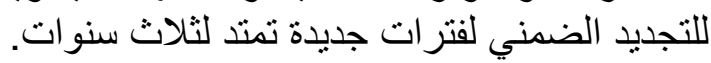

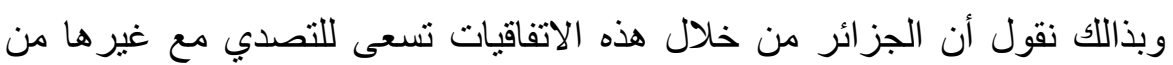

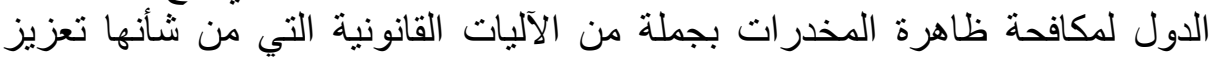
تحقيق سياستها الجنائية فعاليتها المطلوبة لـانة 


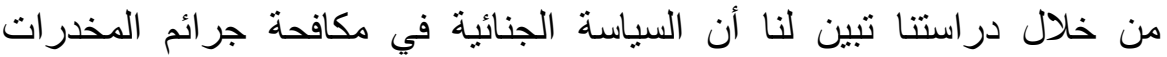
و المؤثر ات العقلية في الجزائر تتمحور حول الونيا الوقاية و العلاج و القمع.

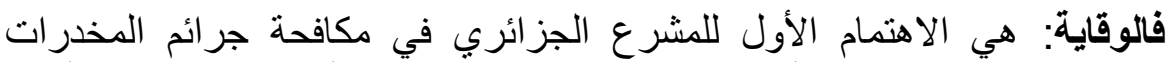

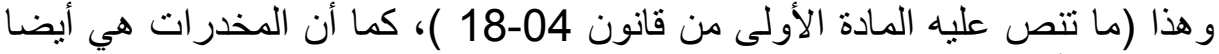

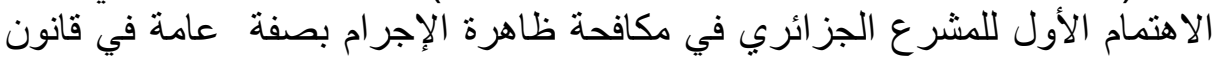

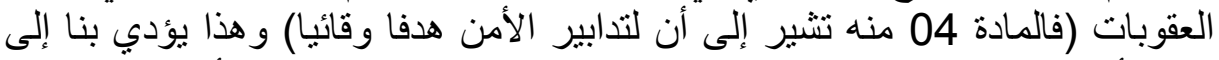

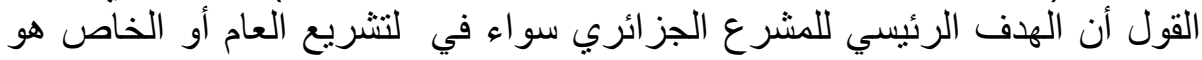

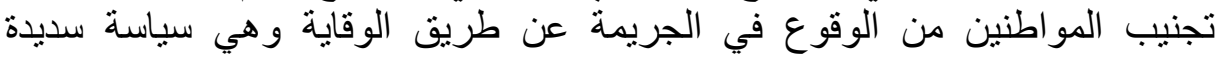
تتماشى والاتجاهات الحديثة في مكافحة الإجر ام.

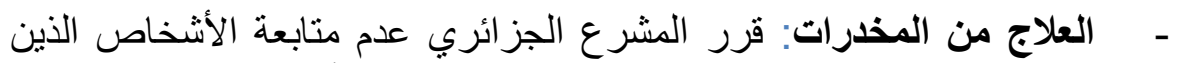

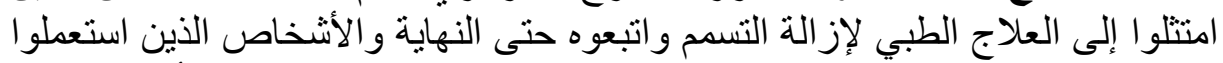

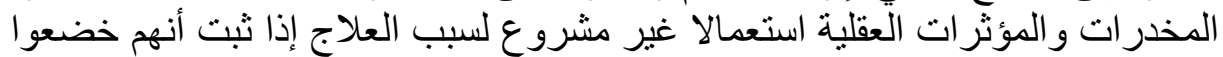

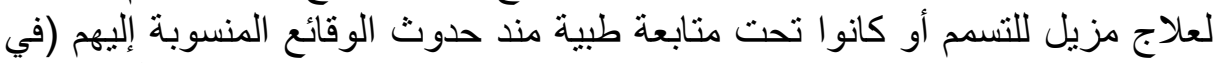

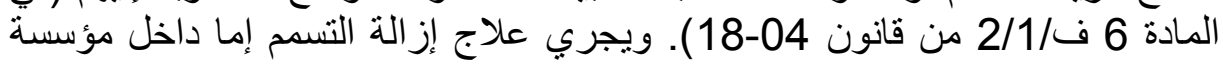

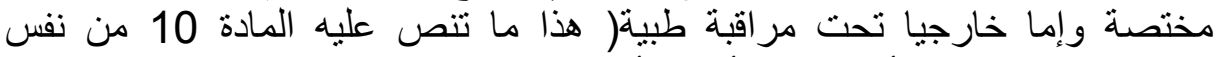

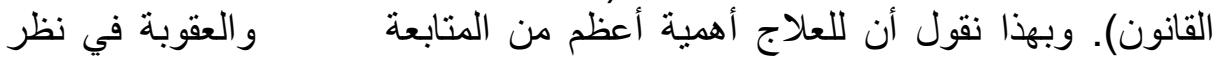

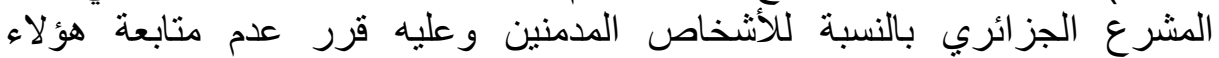

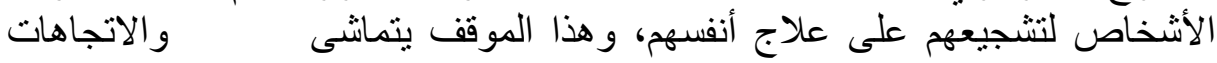

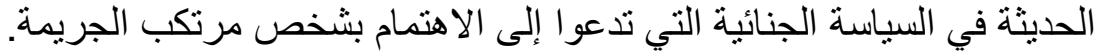

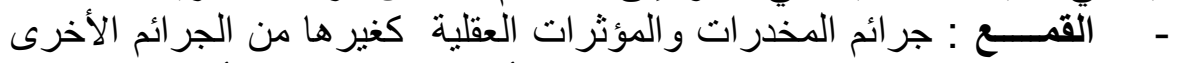

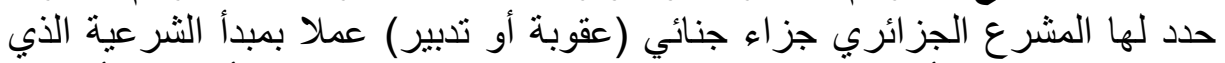

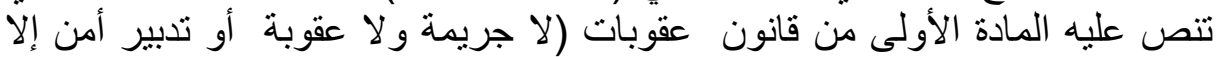

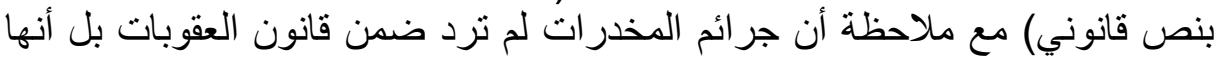

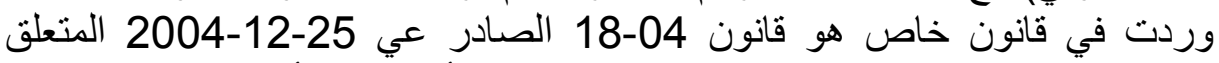

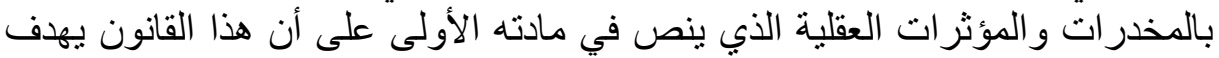

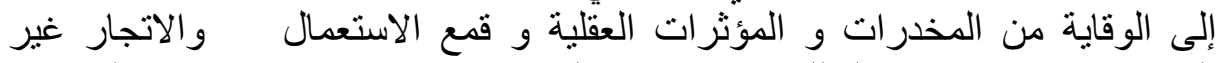

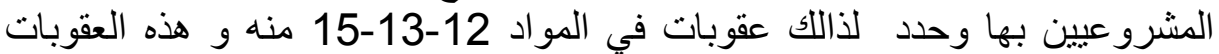

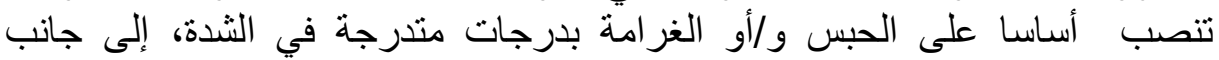

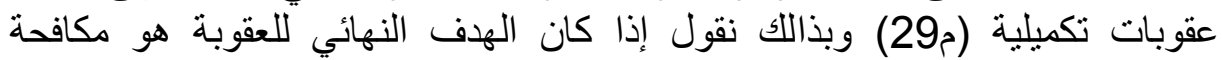

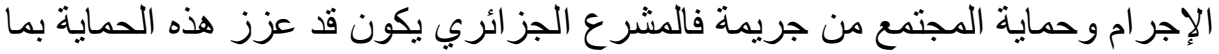

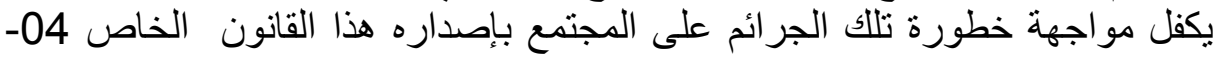




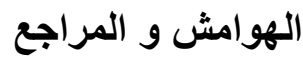

1- الأستاذ نبيل صقر المخع المخدرات في التشريع الجزائري، دار الهدى عين مليلة ، الجزائر سنة

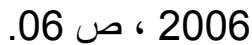

2- الأستاذ نبيل صقر، نفس المرجع السابق ، ص ص 07.

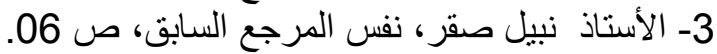

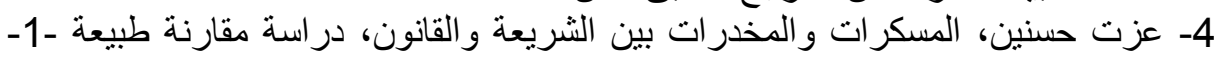

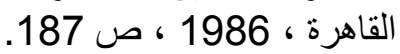

5- محمد عوض، 1986، قانون العقوبات الخاص بجر ائم و والمخدرات و التهرب الجمركي والنقدي،

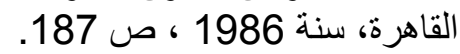

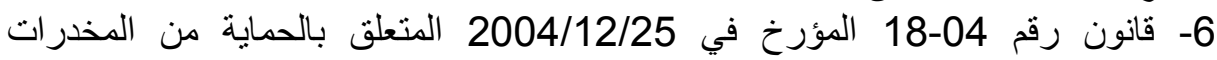

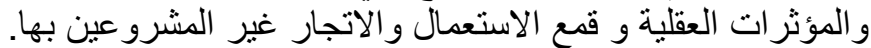

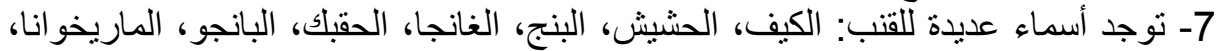

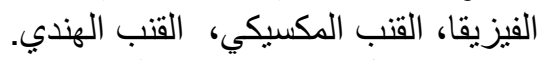

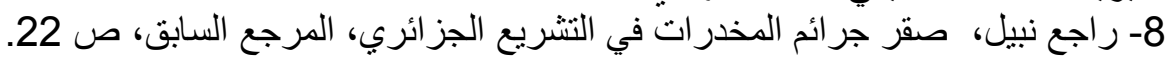

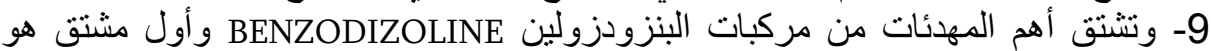

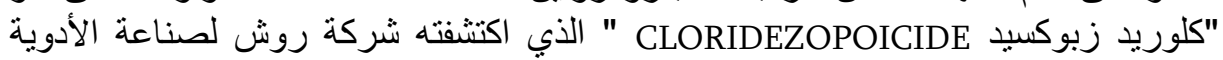

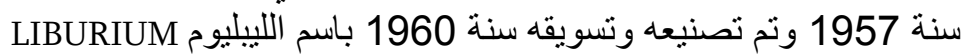

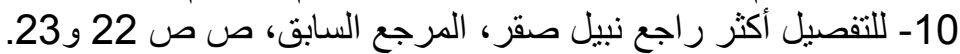

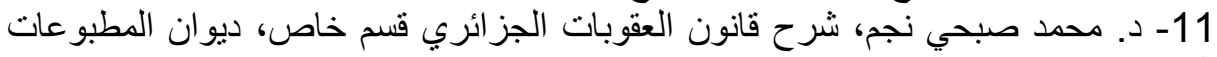

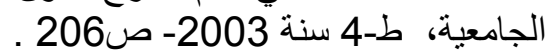

12- د. عبد الله أوهابية، شرح قانون العقوبات الجزائري، القسم العام، الجزائر 2009 ص ص م5 85 13- د. محمود نجيب حسني، شرح قانون العقوبات، القسم العام، دار النهضة العربية، سنة 1962 14- العلمي عبد 1962 الواحد، المبادئ العامة للقانون الجنائي المغربي، الجزء الأول "الجريمة"

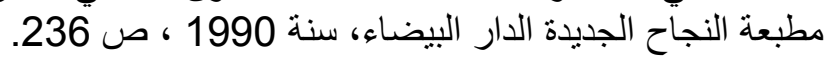
15- د. عبود السراج، قانون العقوبات القياء، القسم العام، منشورات جامعة حلب ، سنة 1986

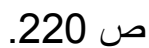
16- لحسن بن الثيخ أث ملويا، المخدرات والمؤثرات العقلية، دار هومة الجزائر، سنة

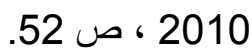
17- ساد في الربع الأخير من القرن التاسع عشر (19) الآراء الإصلاحية الداعية إلى ضرورة إصلاّح الجاني عن طريق الإير الجز اء الجنائي.

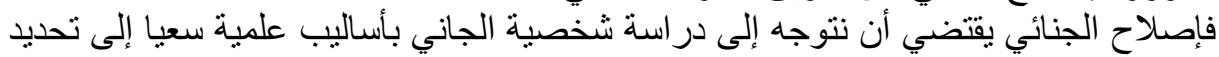

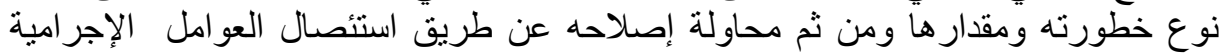

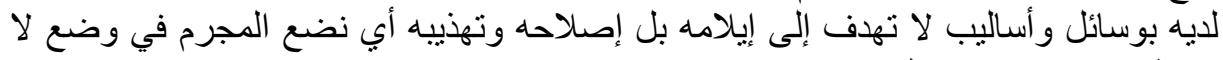

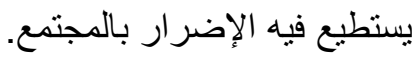

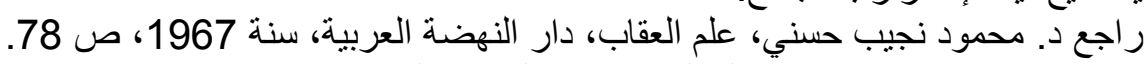
18- د.محمود نجيب حسني، علم العقاب، دار النهضة العربية، سنة 1973، ص ص 35. 
19- د.أحمد فتحي سرور الوسبط في قانون العقوبات، القسم العام، ط-4 ، دار النهضة

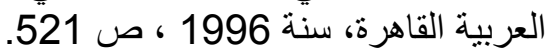

20- عبد الفتاح الصيفي، علم الإجرام والعقاب، مؤسسة الثقافة الجامعية، سنة 1998

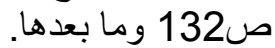
21- د.فتوح ع عبد الله الثاذلي، شرح قانون العقوبات، القسم العام، القاهرة، سنة 2001

22- د. مأمون سلامة، أصول علم الإجر ام و علم العقوبات، سنة 1975، 1975، ص 301.

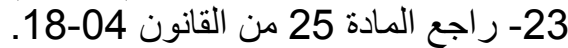

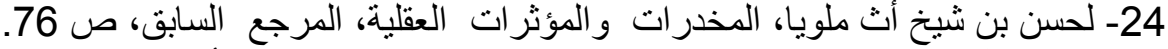

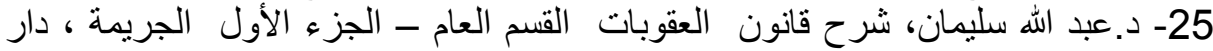

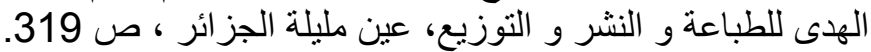

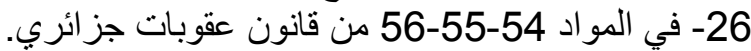

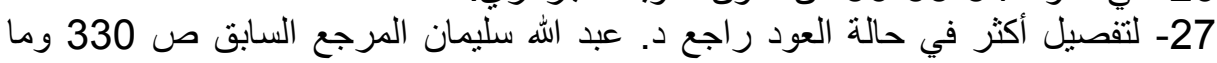

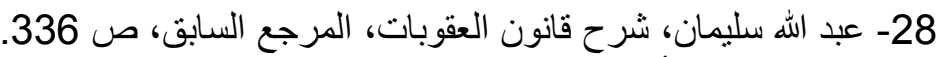

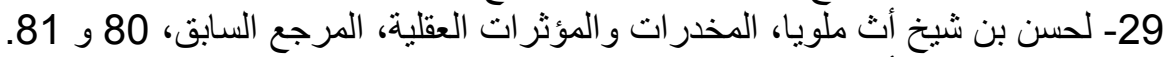

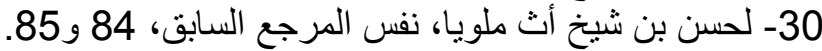

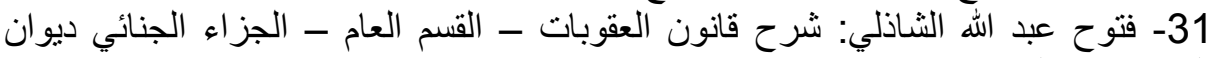
المطبو عات الجامعية، ط 1998 ، 1914 ، ص 342.

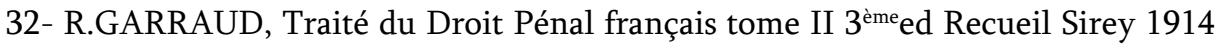
$\mathrm{N}^{\circ} 463$, p 71.

33- فقد تمس العقوبة الحياة فتتخذ صورة الإعدام، وتمس الحرية الثخصية للجاني فتتخذ

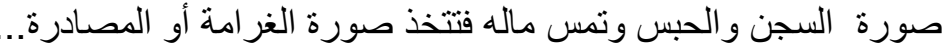
34- راجع د.محمود نجيب حسني، شرح قاله قانون العقوبات، القسم العام، دار النهضة العرة العربية، ط 5 ، السنة 1986 راجع د 1986 ، ص نص 679.

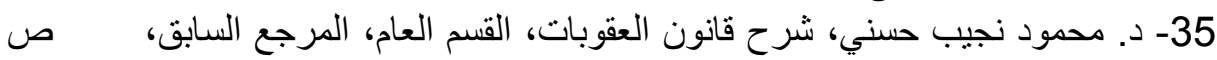

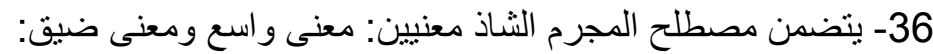

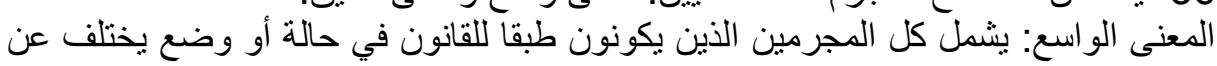
وضع المجرمين العاديين وذللك بسبب حالتهم العقلية الثناذة.

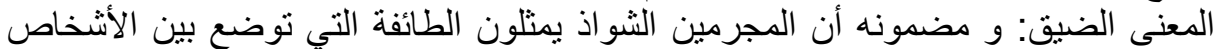

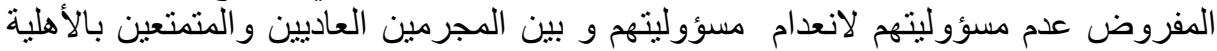

37- د. محمود نجيب حسني، علم العقاب، دار النهضة العربية، سنة 1967، ص ص 73 .74,

38- د.عبد القادر القموجي، د. فتوح عبد الله الثناذلي، علم الإجرام وعلم العقاب،

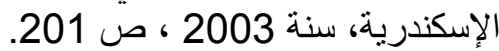
39- د. عبد الله سليمان، النظرية العامة للتدابير الاحترازية، دراسة مقارنة، جامعة القاهرة،

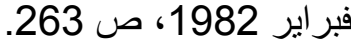


40- أنظر الرأي المخالف عند عبد الله سليمان، النظرية العامة للتدابير الاحترازية، المرجع

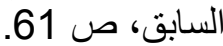

41- د. عبد الله سليمان، شرح قانون العقوبات القسم العام، الجز اء الجنائي، ديوان المطبوعات

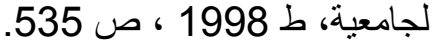

42- ترجم هذا المصطلح إلى اللغة العربية تحت عدة تسميات ففي القانون اللبناني وسوريا

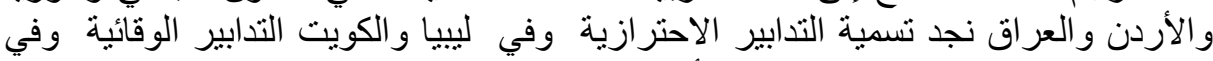
القانون الجزائري نجد تسمية تدابير الأمن.

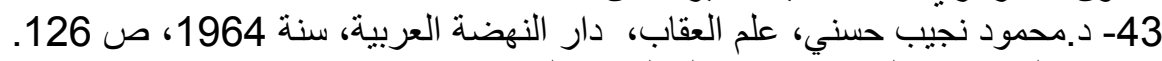

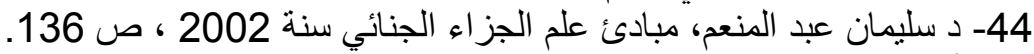

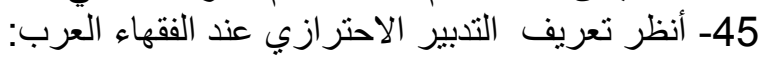

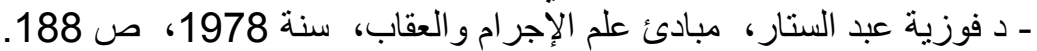

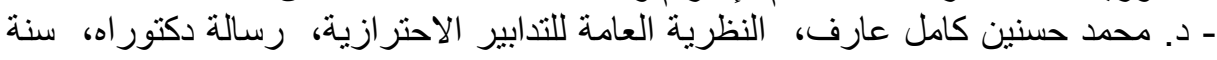

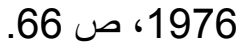

- د.جلال ثروت ،

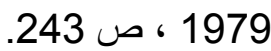
46- د.عبد الله سليمان، النظرية العامة للتدابير الإجرامية، المرجع السابق، ص ص 84

47- MERLE (R.), VITU (A.), Traité de droit criminel- Procédure pénale, $3^{\text {eme }}$ ed ,paris 1978, p 764.

48- د. عبد الله سليمان، النظرية العامة للتدابير الاحتر ازية.

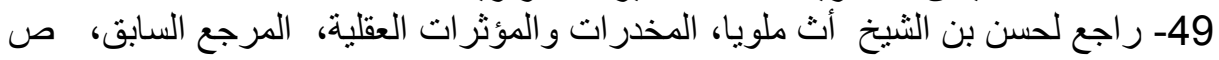

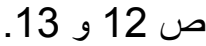

50- من هذا الر أي في الفقه العربي :

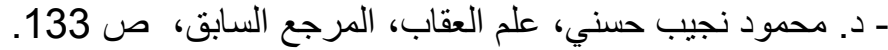

ـ د. جلال ثروة ، الظاهرة الإجرامية، در اسة في علم الإجرام و العقاب، الإسكندرية، سنة

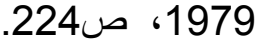

- د. فوزية عبد الستار، مبادئ علم الإجر ام و علم العقاب سنة 1978، ص 136.

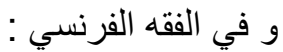

- Merle et Vitu : traite de droit criminel OP Cit ,p 76.

- Stefani Levasseur : Cours de Droit Pénal général Dalloz 1972, p576.

51- راجع د. محمود نجيب حسني، المجرمون الثواذ ، المرجع السابق، ص ص 81 وكذاللك. -Debuste, notion et définition d'état dangereux, Dans le problème de l'état dangereux 1954,p 604.

52- د.أحمد عبد العزيز الألفي ، الحالة الخطرة ، الحلقة العربية الثانية للافاع الاجتماعي القاهرة سنة 1970ص أحس 271 و و ما بعدها.

الخطورة الإجرامية و التدابير الوقائية في التشريع الليبي، المجلة الجنائية القومية نوفمبر

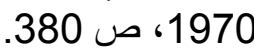

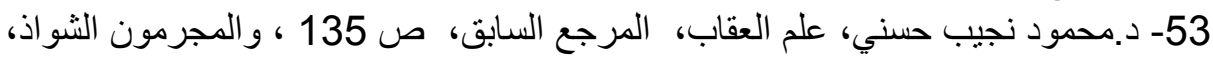
دار النهضة العربية، القاهرة دئ 1964، ص صل 69. 
54- إن فكرة التعاون الدولي لم تكن و اردة قبل ذاللك حيث أن الاعنقاد الذي كان سائدا آنذاك

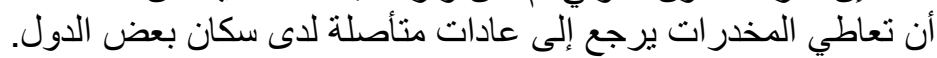

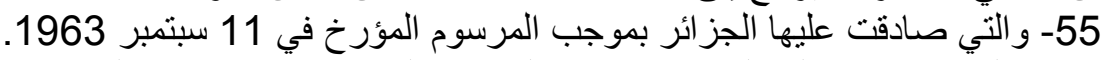
56- و الذي صادقت عليه الجزائر بموجب المرسوم الرئاسي رقّم 02-02-61 المؤرخ في 25.2002-02

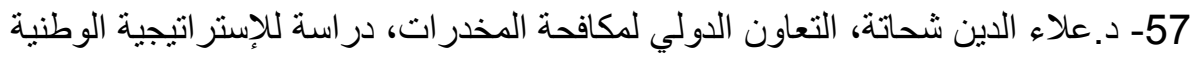

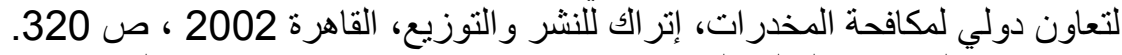

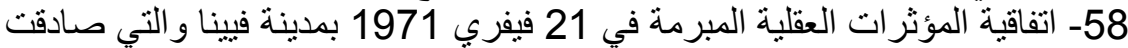

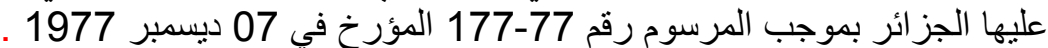

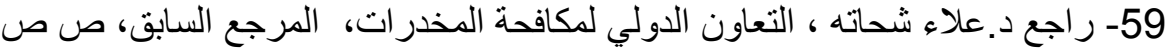
322,321 60- تمتد الحدود الجزائرية على 6000 كم أكثر ها موجود في مناطق صحر اوية صعبة

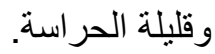
61- نبيل صقر ، جرائم المخدرات في التشريع الجزائري ، دار الهدى عين مليلة، الجزائر

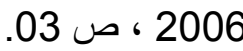
62- الجريدة الرسمية ، العدد 77 لسنة 2007 ، ص ص 3 و 4. 